\title{
BOLIVIAN PUBLIC FINANCES, 1882-2010. THE CHALLENGE TO MAKE SOCIAL SPENDING SUSTAINABLE *
}

\author{
JOSÉ ALEJANDRO PERES-CAJÍAS
}

Universitat de Barcelona $^{\text {a }}$

\begin{abstract}
This paper offers a long-term comparative study of Bolivian public finances using a new detailed database. First, it shows that Bolivian government revenues and expenditures were particularly small and volatile until the 1980s. Second, it stresses that, whereas the relative importance of social expenditure has grown constantly since the late 1930s, public revenues have always had an unbalanced structure. Finally, it confirms that budget deficits have been constant, at times reaching levels that were especially damaging for the overall economy. This suggests that the potential redistributive impact of Bolivian public finances was not necessarily (or not only) hindered by the lack of an explicit commitment towards redistributive expenses, but by an extreme vulnerability in the revenue side.
\end{abstract}

Keywords: public finances, social public spending, taxes, Bolivia

JEL Code: H10, H20, H50, N46

* Received 20 September 2013. Accepted 9 January 2014. This research has benefited from financial support from the University of Barcelona through the APIF (2008-2012) fellowship program; from the Science and Innovation Ministry of Spain through project ECO2009-13331-C02-02; from the Catalonian Research and Universities Grant Agency through the BE-DGR 2011 fellowship program. The author specially thanks Alfonso Herranz Loncán for his constant support and critical readings of previous drafts. The author also thanks Paola Azar, Luis Bértola, Sebastián Fleitas, Ewout Frankema, Herbert Klein, Fernanda Wanderley and three anonymous referees for their valuable comments on previous drafts. The usual disclaimer applies.

a Departament de Història i Institucions Econòmiques. Av. Diagonal 690, Edifici Principal Torre 2, Planta 4, 08034, Barcelona (Spain). joseperescajias@gmail.com 


\section{RESUMEN}

Este trabajo ofrece un estudio comparativo y de largo plazo de la hacienda pública boliviana mediante una base de datos desagregada. En primer lugar, muestra que los ingresos y gastos públicos fueron bajos y volátiles hasta los 1980s. En segundo lugar, demuestra que mientras la importancia relativa del gasto social se incrementó desde finales de los 1930s, los ingresos públicos mantuvieron una estructura desequilibrada. Finalmente, confirma que los déficits presupuestarios fueron constantes, llegando a alcanzar algunas veces niveles perjudiciales para el resto de la economía. Ello sugiere que el impacto redistribuidor de la hacienda pública boliviana no estuvo necesariamente (o no solo) restringido por la falta de apoyo explícito a gastos redistributivos, sino por una vulnerabilidad considerable en los ingresos.

Palabras claves: Hacienda Pública, gasto público social, impuestos, Bolivia

\section{INTRODUCTION}

During recent years, the Bolivian government has taken advantage of the commodity trade boom on global markets in order to foster redistributive policies (CEPAL 2010; PNUD 2010). For instance, by increasing the fiscal burden on oil and gas exploitation, the government has fuelled different programmes aimed at the expansion of social public expenditure ${ }^{1}$. Furthermore, given this increasing fiscal burden and thanks to the high price of oil and gas on world markets, budget deficits have been substantially reduced to the extent that some years have closed with fiscal surpluses. Whereas these achievements may represent a positive change, some scholars are skeptical about any long-term positive consequence. For instance, it has been argued that the current fiscal burden on gas and oil activities hampers the long-term sustainability of the sector ${ }^{2}$. Others add that although fiscal surpluses represent a positive change, dependence on natural resources revenues may increase the vulnerability of the system to the evolution of the global economy (see Fundación Jubileo 2012b). In the same vein, it has been stressed that a non-negligible share of the increase in public spending has been «wasted» on

\footnotetext{
1 For an analysis of the increasing fiscal burden on oil and gas exploitation, see Fundación Jubileo (2011, 2012a).

2 See del Granado et al. (2010), Medinaceli (2012) and Fundación Jubileo (2013). These works suggest that new investments are necessary to assure the long-term sustainability of the sector. According to these authors, these investments will not arrive to the country unless some legislative changes are implemented.
} 
unproductive expenses and did not necessarily benefit the less favoured components of the Bolivian population ${ }^{3}$.

The aim of this paper is to contribute to this debate from a historical perspective and to identify some of the limitations which previously restricted the effectiveness of state intervention. To this end, it offers new detailed quantitative evidence which differentiates it from previous research on the historical evolution of Bolivian public finances. Indeed, while earlier research on this topic has focused on specific periods of the $20^{\text {th }}$ century, the present study covers more than 120 years of the history of the Republic ${ }^{4}$. Moreover, while Gallo (1991) offers evidence on the composition of expenditure for the period 1911-1950 only, the database that is presented in this paper provides complete evidence of both expenditure and revenue composition since $1900^{5}$. In addition, this paper benefits from the reconstruction of the Bolivian GDP elaborated by Herranz and Peres-Cajías (2013) and offers for the first time a long-term and comparative study of several Bolivian fiscal indicators in relative terms.

Using this new quantitative evidence, the paper shows that Bolivian government revenues and expenditures were particularly low and volatile until the late 1980s. The paper also proves that the importance of social public expenditure within total public spending has been growing since the late 1930s. As for the structure of public revenues, the paper stresses that, besides some modifications in the relative importance of each category, the Bolivian government has always had an unbalanced structure: from the last quarter of the $19^{\text {th }}$ century to the early 1980s, the state was highly dependent on international trade taxes; later on, on indirect internal taxes and revenues derived from oil and gas exploitation. Finally, the paper shows that, largely because of this extreme dependence on certain revenue sources, central government revenues have usually been insufficient to cover expenditures, thus fostering constant budget deficits which sometimes reached a level that was especially damaging for the overall economy. The inflationary process from May 1984 to September 1985 — one of the highest in world history — is certainly the most salient example of this negative impact.

Hence, this historical analysis suggests that the recent expansion of social public expenditure does not represent a new feature but an acceleration of

${ }^{3}$ Guzman et al. (2010) propose a new institutional scheme that may help to redirect public spending to those items which would reduce the extreme dependence of the economy on the exploitation of natural resources. See also Candia et al. (2013). See Hinojosa (2012) and Paz et al. (2013) for the impact of social spending on inequality.

4 Contreras (1990), for instance, studies the years 1920-1935, whereas Gallo (1991) and Barragán and Peres-Cajías (2007) focus on the first half of the $20^{\text {th }}$ century.

5 Other previous analyses of the composition of Bolivian public revenue and expenditure also cover short time spans, such as Palenque (1933) (which covers the 1911-1931 period), Wilkie (1969) (who provides data for 1930-1966), and the IMF and ECLAC estimates (which provide data from the 1970s onwards). Therefore, to date and to my knowledge, the new dataset presented in this paper represents the first disaggregated estimation with such a long time span. 
one of the most significant characteristics of Bolivian public finances over most of the $20^{\text {th }}$ century. This finding requires further research in order to analyse who benefited from the expansion of social spending and to identify its impact on the evolution of Bolivian social indicators. However, the aforementioned findings would also suggest that the potential redistributive impact of Bolivian public finances has not been necessarily, or not only, restricted by the lack of an explicit commitment towards redistributive expenses, but by an extreme vulnerability on the revenue side. Therefore, in line with previous studies (Engel et al. 1999; Breceda et al. 2009; Goñi et al. 2011), this paper stresses that the current debate in Latin America and Bolivia about the effectiveness of redistributive policies should focus not only on the allocation of public spending, but also on those policies which may ensure a sustainable flow of revenues.

\section{THE NEW BOLIVIAN PUBLIC FINANCE DATABASE}

Until the end of the $20^{\text {th }}$ century, most analyses of the long-term evolution of Latin American public finances were primarily based on the Argentinean, Brazilian and Mexican experiences (Topik 1987; Díaz-Fuentes 1999; Bordo and Cortés-Conde 2001; Cortés-Conde 2006; Comín and Díaz-Fuentes 2007; Sánchez-Santiró 2011). During the last few years, interest in the fiscal history of other Latin American countries has increased, involving both high-income economies such as Chile (Wagner et al. 2000), and low-income countries such as Guatemala (ICEFI 2007). In most cases, historical narratives on the topic have been accompanied by detailed long-term databases (Junguito and Rincón 2004; Azar et al. 2009). This paper adds a new case study to this growing literature by analysing the Bolivian case and offering detailed longterm series of both public revenue and expenditure ${ }^{6}$.

The new dataset is based on exhaustive archival research both in Bolivia and abroad, which has made it possible to identify the main primary and secondary sources of the long-term evolution of Bolivian public revenues and expenditures ${ }^{7}$. The distribution of revenue and expenditure among the different categories has followed the most widely accepted international definitions (IMF 2001). Expenditures have been allocated to each category according to the ministry in charge. As for revenues, when the nature of a specific revenue was not clear, I have based its classification on the analysis

${ }^{6}$ Public finances is a field of analysis with elements from different disciplines and, therefore, has been studied using different approaches. For a methodological discussion on this issue, see Lamb et al. (2005); for the study of different approaches to the history of public finances in developing economies, see Brautigam et al. (2008); for an analysis of the historiography of public finances in a Latin American country, see Jáuregui (2003).

${ }^{7}$ See the methodological appendix for a complete description of sources, estimation methods and reliability checks. 
of tax and income legislation ${ }^{8}$. Because of data availability constraints, the series include total (current plus capital) expenditure, but only current (and not capital) revenues. Hence, the database is organised according to an adapted version of the IMF functional classification (IMF 2001) which considers six categories and three sub-categories in the case of expenditures and three general categories with several sub-categories in the case of revenues.

Additional data restrictions have affected the estimation. For instance, the initial year of each series - 1882 in the case of revenues and 1900 in the case of expenditures - is determined by the availability of data. Furthermore, the discovery of substantial differences between cash and budgeted flows for those years for which both data are available prevented me from using budget information - even in those few years for which no data on the cash flows could be found ${ }^{9}$. Hence, unlike previous work (Barragán and Peres-Cajías 2007), my database is always based on cash revenue and expenditure flows. In this regard, since there are no systematic data for the cash revenues and expenditures of either the departments or the municipalities between 1882 and 1989, my series only include the public finances of the central government from 1882 to 2010, and that of general government from 1990 onwards.

Despite these coverage limitations, the new database constitutes a reasonably good approximation to the main features of the history of Bolivian public finances from the last quarter of the $19^{\text {th }}$ century onwards. First, the Law of 21 November 1872, divided Bolivian public finances into three different administrations - the National Treasury, the Departmental Treasuries and the Municipal Treasuries - and officially recognised the end of the central government's dependence on the indigenous capitation tax and the consolidation of international trade taxes as the main revenue source. This fiscal change and the political stability achieved after Bolivia's defeat in the Pacific War (1879) against Chile fostered a state-building process (Klein 2011) that may be approached through the evolution of central government revenues since the early 1880 s.

Second, the focus on central government's statistics makes it possible to study the most important part of Bolivian public finances during most of the time analysed by the present work. It is true that after the Law of 1872 none of the three fiscal administrations had a clear prominence over the others (see Platt 1982). For example, in 1882 the departments' revenues were equivalent to 40 per cent of the central government's revenues. However, a

8 Legal information comes from the CD-database Legislación Boliviana 1825-2007, made available by the Biblioteca y Archivo del Honorable Congreso Nacional, and from different tax and revenue compilations: Mc Queen (1925), Presupuesto de la República de Bolivia 1931, Banco Minero de Bolivia (1941), Pando (1941) and UDAPE (1985).

9 A comparison between cash and budgeted revenues of the Bolivian central government between 1885 and 1959 shows persistent differences between them, which were substantial — often higher than 25 per cent — and random over time. 
progressive centralisation process has taken place since the mid-1900s and the size of the departments' budgets had decreased to ca. 10 per cent of the central government's revenues and expenditures ${ }^{10}$. The Great Depression and the loss of the Chaco War (1932-1935) against Paraguay reinforced this centralisation process, which was reflected both in legislation (Barragán 2007) and in the structure of public finances: between the 1930s and the 1980s the departments' budgets represented, on average, 5 per cent of the central government's revenues and expenditure (Wilkie 1969; Otálora 1995; Barragán and Peres-Cajías 2007). Hence, since they represented more or less 90 per cent of total Bolivian public finances, central government statistics may be considered a good proxy of the total revenue and expenditure of Bolivian public administrations for most of the $20^{\text {th }}$ century.

Departmental and municipal finances regained relevance from the late 1980s onwards. To start with, the tax reform of 1986 established that public revenues collected by the central government had to be reallocated to different administrations: 75 per cent to the central government, 10 per cent to the departments, 10 per cent to the municipalities and 5 per cent to the universities (Otálora 1995, p. 107). These shares and the functions of the different administrations were subsequently modified by the Ley de Participación Popular (Popular Participation Act, 1994), the Ley 1654 de Descentralización Administrativa (Administrative Decentralization Act, 1995) and the most recent legislation on oil and gas activities (2005) (Pereira et al. 2012). As a result of these processes, both department and municipal resources increased their relative importance as a share of the general government's total receipts. However, as highlighted in the next section, the implications of these changes can be analysed easily thanks to the availability of general government statistics from 1990 onwards.

\section{BOLIVIAN PUBLIC REVENUES AND EXPENDITURES, 1882-2010: SOME STYLISED FACTS}

The present section uses the new database to describe some of the most important stylised facts of the history of Bolivian public finances since the late $19^{\text {th }}$ century ${ }^{11}$. The first is the low level of the ratio between public revenues and GDP until recent decades (Figure 1). Between 1882 and the late 1950s, central government's revenues were, on average, around 5 per cent of GDP. Thereafter and until the first half of the 1980s, they increased slightly but - with the exception of some years - remained below 10 per cent of GDP.

10 The estimation of the relative importance of each fiscal administration - national, departmental and municipal - was obtained using the different sources specified in the methodological appendix. See also Barragán and Peres-Cajías (2007).

11 Five year averages of the main categories of public revenues and expenditures are provided in the appendix. The full database is available upon request. 
FIGURE 1

BOLIVIAN CENTRAL AND GENERAL GOVERNMENT'S REVENUES AS A

SHARE OF GDP (LEFT-AXIS) AND PER CAPITA (RIGHT-AXIS), 1882-2010 (\%; BS. 2000).

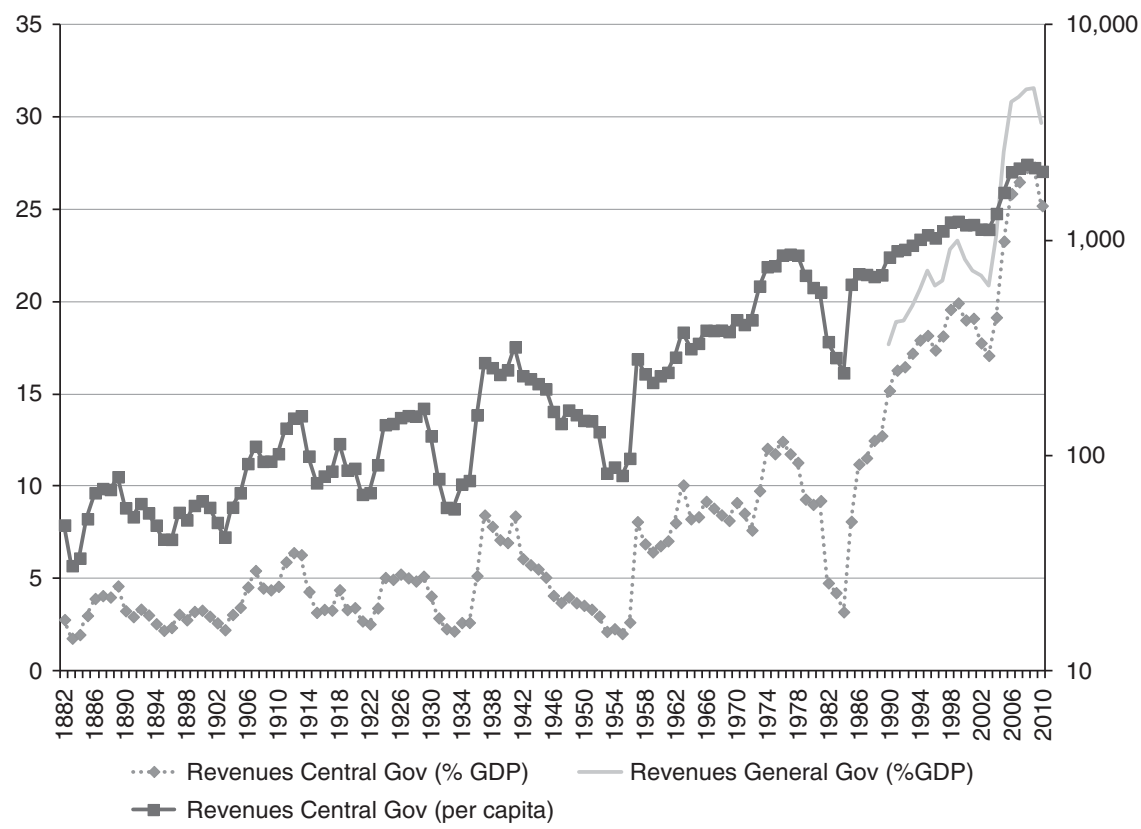

Sources: For GDP, from 1882 to 1950, Herranz and Peres-Cajías (2013); from 1950 to 2010, from ECLAC database: www.eclac.cl; for population, see Herranz and Peres-Cajías (2013); for prices and revenues, see text.

They only surpassed that level in the second half of the 1980s and subsequently continued to grow, reaching a level of 25 per cent of GDP in the late 2000s. Differences between central government's revenues and general government's revenues were not significant until 2005, when departmental and municipal revenues increased their relevance as a result of the new legislation on oil and gas activities.

A regional comparison confirms the low level of Bolivian central government revenues for most of the period under study (Table 1). Indeed, during the last quarter of the $19^{\text {th }}$ century, whereas Bolivian revenues remained around 3 per cent of GDP, Chilean figures were around 8 per cent of GDP. During the first half of the $20^{\text {th }}$ century, Bolivian public revenues were around 4.5 per cent of GDP, a figure more or less similar to those of Colombia and Peru, but far from the ratios in Chile and Uruguay. From 1952 to 1985 , Bolivian public revenues reached on average around 7 per cent of 
TABLE 1

LATIN AMERICAN CENTRAL GOVERNMENT'S REVENUES AS A SHARE OF GDP, 1882-2010 (\%, TEN YEAR AVERAGES)

\begin{tabular}{|l|c|c|c|c|c|c|}
\hline & Bolivia & Chile & Colombia & Guatemala & Peru & Uruguay \\
\hline $1882-1889$ & 3.27 & 7.59 & N.a. & N.a. & N.a. & N.a. \\
\hline $1890-1899$ & 2.88 & 8.26 & N.a. & N.a. & N.a. & N.a. \\
\hline $1900-1909$ & 3.65 & 9.46 & 5.04 & N.a. & 4.35 & 11.90 \\
\hline $1910-1919$ & 4.51 & 7.87 & 3.87 & N.a. & 4.35 & 10.22 \\
\hline $1920-1929$ & 4.24 & 10.80 & 3.69 & N.a. & 4.55 & 11.05 \\
\hline $1930-1939$ & 4.52 & 12.70 & 4.72 & N.a. & 6.08 & 12.94 \\
\hline $1940-1949$ & 5.33 & 14.19 & 6.07 & 9.08 & 8.38 & 12.14 \\
\hline $1950-1959$ & 4.04 & 15.29 & 7.78 & 8.18 & 13.63 & 13.61 \\
\hline $1960-1969$ & 8.32 & 17.49 & 8.47 & 8.21 & 15.13 & 14.28 \\
\hline $1970-1979$ & 10.37 & 26.22 & 10.95 & 9.25 & 15.41 & 15.72 \\
\hline $1980-1989$ & 8.66 & 27.09 & 12.02 & 8.66 & 12.46 & 17.21 \\
\hline $1990-1999$ & 17.64 & 21.24 & 9.03 & 10.43 & 14.40 & 17.60 \\
\hline $2000-2010$ & 22.51 & 22.52 & 12.20 & 12.19 & 15.89 & 20.63 \\
\hline
\end{tabular}

Notes: N.a.: Not available.

Sources: (a) Bolivia, see text; (b) other countries from 1900 to1989; Chile: Base de datos EH CLIO LAB, Iniciativa Científica Milenio Mideplan; Colombia: Kalmanovitz (2011); Guatemala: ICEFI (2007); Peru: Portocarrero, Beltrán and Romero (1992); Uruguay: Azar et al (2009); (c) other countries from 1990 to 2010 from ECLAC database: www.eclac.cl.

GDP, one of the lowest figures in Latin America. Thus, it was not until the 1990s when Bolivian public revenues started to converge with the regional average. Nowadays, the Bolivian ratio between central - as well as general government's revenues and GDP is among the highest in the region ${ }^{12}$.

Expenditures were generally higher than revenues, but the ratio between public expenditures and GDP was also low until recent decades (Figure 2). Bolivian central government's spending was around 5 per cent of GDP until

12 Interestingly, Table 1 suggests the existence of at least two different varieties of public finances in Latin America. On the one hand, public revenues in countries such as Chile and Uruguay were already higher than 10 per cent of GDP in the first third of the $20^{\text {th }}$ century. On the other hand, public revenues in countries such as Bolivia or Colombia were below or around 10 per cent of GDP even until the last decade of the $20^{\text {th }}$ century. These fiscal variations within the region are also noticeable in relation to the composition of public revenues (see below) and highlight the need for further research to analyse why some Latin American countries had a higher fiscal capacity than others throughout the $20^{\text {th }}$ century. 
FIGURE 2

BOLIVIAN CENTRAL AND GENERAL GOVERNMENT'S EXPENDITURES AS A SHARE OF GDP (LEFT-AXIS) AND PER CAPITA (RIGHT-AXIS), 1900-2010

(\%; BS. 2000).

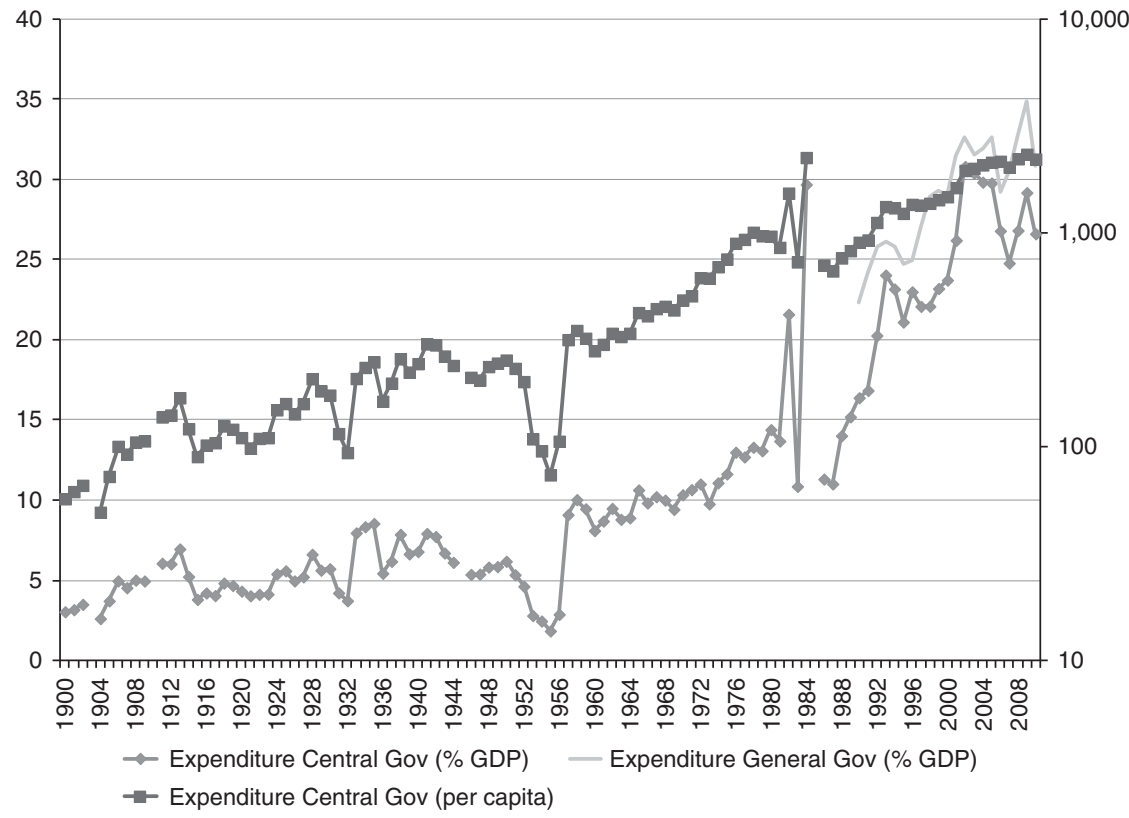

Source: See Figure 1.

the late 1950s, when it started growing steadily. Despite this increase, central government spending was still below 15 per cent of GDP in the late 1970s. During the early 1980s, central government's spending soared, which led to serious macroeconomic disorder that was only controlled in the last months of 1985. Some important reforms were implemented thereafter and central government spending started to grow again on sounder bases up to ca. 25 per cent of GDP in the late 2000s. Differences between central and general government's expenditures during the 1990s were somehow higher than in the case of revenues, but still modest until the mid-2000s.

Beyond the low level of both Bolivian public revenues and expenditures until recently, the graphs also stress the intense fluctuations in both variables. The intensity of these fiscal fluctuations can be measured by estimating the volatility of real public revenues and expenditures (Table 2$)^{13}$. The estimations

13 Before 1931 price changes were estimated as the three year moving average of the product of the British CPI and the Bolivian peso/pound sterling exchange rate. See Herranz and Peres-Cajías 
stress that, in general terms, the volatility of both variables tended to decrease over time and to be higher in the case of revenues. However, during the 1930s, 1950s and 1980s, volatility levels sharply increased compared to the previous decades and, moreover, during the 1950s and 1980s volatility was higher in expenditures than in revenues ${ }^{14}$. Since the 1990 s, by contrast, volatility levels of both public revenues and expenditures experienced a significant decrease and reached the lowest levels in the history of Bolivian public finances.

Therefore, the previous evidence shows that Bolivian public finances were particularly restricted for a long time by their small size relative to the aggregate economy as well as by the volatility of the resources available. In order to understand the reasons for the persistence of these restrictions as well as the driving forces of the recent changes, the next section analyses the composition of both public revenues and expenditures.

\section{BOLIVIAN PUBLIC SPENDING: WHERE WAS IT ALLOCATED AND HOW WAS IT FINANCED?}

The present section focuses on the composition of Bolivian public finances throughout the period under study. In the case of expenditures, Figure 3 shows that, at the beginning of the $20^{\text {th }}$ century, the Bolivian central government was concentrated on general administration, defense and economic expenditures. However, during the second half of the 1900s, the share of social expenditure within central government spending started to increase and reached 10 per cent $^{15}$. This structure remained stable until the Chaco War (1932-1935), when defense spending soared to 80 per cent of total spending. After the war, the relative importance of defense expenditures decreased significantly, whereas social spending started to increase once more. The relative importance of the latter grew once more after 1956 in a process that, despite some oscillations, lasted until the beginning of the $21^{\text {st }}$ century, when it reached a level of around 50 per cent of central government spending ${ }^{16}$.

(F'note continued)

(2013) for the validity of this methodology. From 1931 onwards price changes were obtained from official statistics.

${ }^{14}$ Indeed, the volatility of Bolivian public revenues and expenditures became significantly higher than in other Latin American countries during these decades. For instance, during the 1930s and 1950s, Bolivian figures were three times higher than those of Uruguay. During the 1980s, Bolivian figures were four times higher than those of Chile. By contrast, volatility of both Bolivian public revenues and expenditures, were not radically different from those of Chile and Uruguay during the remaining decades of the $20^{\text {th }}$ century.

15 General Public Services includes the spending made by the Executive, the Legislative, Foreign Affairs, and Public Debt transactions (IMF 2001, pp. 79-82). See the appendix to appreciate the relatively high importance of Public Debt transactions during the first third of the $20^{\text {th }}$ century. See the appendix also to appreciate the composition of social public spending. See the methodological appendix and IMF (2001, p. 76) for a complete presentation of expenditure classification.

16 The ratio is similar in the case of general government expenditures. 
TABLE 2

PUBLIC REVENUE AND EXPENDITURE VOLATILITY, 1880-2010 (TEN YEAR AVERAGES)

\begin{tabular}{|l|c|c|c|c|c|c|c|c|c|c|c|c|c|}
\hline & $\mathbf{1 8 8 0 -}$ & $\mathbf{1 8 9 0 -}$ & $\mathbf{1 9 0 0 -}$ & $\mathbf{1 9 1 0 -}$ & $\mathbf{1 9 2 0 -}$ & $\mathbf{1 9 3 0 -}$ & $\mathbf{1 9 4 0 -}$ & $\mathbf{1 9 5 0 -}$ & $\mathbf{1 9 6 0 -}$ & $\mathbf{1 9 7 0 -}$ & $\mathbf{1 9 8 0 -}$ & $\mathbf{1 9 9 0 -}$ & $\mathbf{2 0 0 0 -}$ \\
$\mathbf{1 8 8 9}$ & $\mathbf{1 8 9 9}$ & $\mathbf{1 9 0 9}$ & $\mathbf{1 9 1 9}$ & $\mathbf{1 9 2 9}$ & $\mathbf{1 9 3 9}$ & $\mathbf{1 9 4 9}$ & $\mathbf{1 9 5 9}$ & $\mathbf{1 9 6 9}$ & $\mathbf{1 9 7 9}$ & $\mathbf{1 9 8 9}$ & $\mathbf{1 9 9 9}$ & $\mathbf{2 0 1 0}$ \\
\hline Revenues & 0.27 & 0.18 & 0.19 & 0.24 & 0.19 & 0.37 & 0.16 & 0.40 & 0.12 & 0.16 & 0.38 & 0.06 & 0.11 \\
\hline Expenditures & N.d. & N.d. & 0.17 & 0.20 & 0.16 & 0.36 & 0.12 & 0.45 & 0.10 & 0.07 & 0.54 & 0.08 & 0.07 \\
\hline
\end{tabular}

Notes: N.d.: no data.

Sources: Volatility has been calculated on the basis of the new database as the standard deviation of $\ln \left(X_{t} / X_{t-1}\right)$, being $\mathrm{X}$ revenue or expenditure in real terms; see Jacks, O’Rourke and Williamson (2011). 
FIGURE 3

CENTRAL GOVERNMENT'S EXPENDITURE COMPOSITION, 1900-2010 (SHARE OF TOTAL EXPENDITURE, \%)

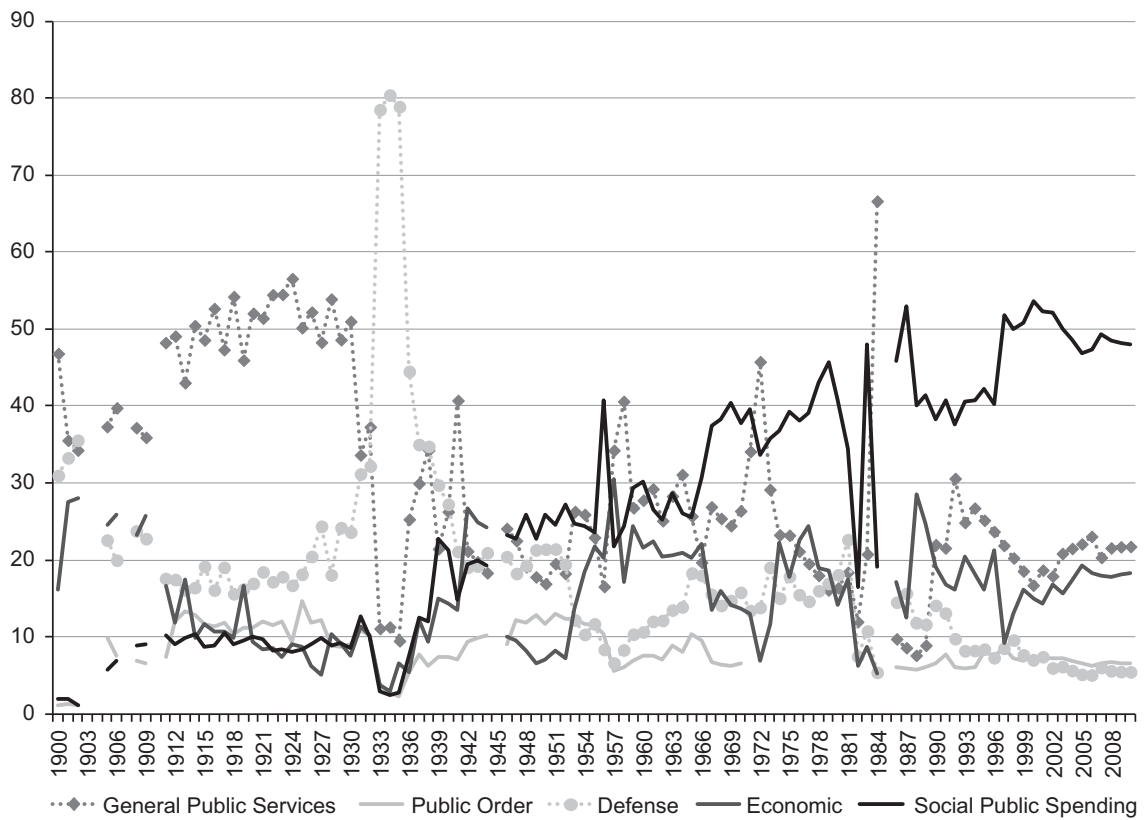

Sources: See text.

Notes: From 1971 to 1984, General Public Services includes Public Order.

Hence, the increasing relevance of social public expenditure is clearly one of the most important features of the history of Bolivian public finances over most of the $20^{\text {th }}$ century. The initial push was associated with the centralisation of education and the educational reform embraced by the liberal governments (Cajías 2011) ${ }^{17}$. Further increases were driven by the centralisation of health spending during the years of the so-called Military-Socialist regimes (1936-1939) as well as by an important increase in education spending (Barragán and Peres-Cajías 2007) ${ }^{18}$. These last changes were linked with the

17 In effect, whereas in 1903 (before centralisation), the budgeted education expenditure of the Departmental and the National Treasuries were Bs. 263,213 and Bs. 128,320, respectively, 10 years later (once centralisation and educational reform were underway) the equivalent figures were Bs.137,850 and Bs. 2,447,950, respectively. In other words, the total public expenditure in education was multiplied by a factor of six in just one decade.

18 The Bolivian case, therefore, would confirm the hypothesis by Sokoloff and Zolt (2006) which stresses that the expansion of social public spending in Latin America was correlated with the centralisation of public finances. It must be noted, however, that the expansion of social spending 
emergence of new economic and political groups (such as urban middle classes or the mining and urban workers) and the response to their political demands by some of the governments that held power after the Chaco War (Wilkie 1969; Dunkerley 2003; Klein 2011, pp. 178-208).

The revolution of 1952 represented a new landmark in the prioritisation of social spending. The revolution brought about an aggressive redistribution of land, the nationalisation of the three largest mining companies and the establishment of universal franchise. These changes involved a considerable increase in the intervention of the state in the economy and were justified as the best way to achieve two of the main goals of the revolution: economic redistribution and the diversification of the economy. Under these circumstances and the constant pressure from the social movements which made the revolution possible - namely urban and rural workers - social spending grew substantially once the initial macroeconomic imbalances provoked by the revolution were corrected (Dirección Nacional de Informaciones 1962). Although some of the priorities of the revolution were radically modified during the time of military dictatorships (1964-1982) and beyond, the ideological differences among these different military governments ${ }^{19}$, social public expenditure and, particularly, education spending continued to increase during the 1960 s and 1970 s.

Once democracy had been restored (1982), the expansion of social expenditure was not only driven by education spending but also by health and welfare expenditures. From 1985 to the early 2000s, this increase was related with the implementation of a new economic model which, following the Washington Consensus guidelines (Williamson 2004), paid particular attention to social public spending ${ }^{20}$. In contrast, the expansion of social public expenditure from the mid-2000s onwards is associated with the interest of Evo Morales' administration - which explicitly rejects the Washington Consensus paradigm - in the expansion of social services across the entire country (PNUD 2010). This process highlights, once more, that the current importance of social public expenditure appears as the accumulation of policies applied by different governments which very often embraced opposing ideologies ${ }^{21}$.

\footnotetext{
(F'note continued)

during the 1990s (see below) was correlated with a devolution process to municipalities. This contrast stresses that the alleged correlation between centralisation and the expansion of social spending must not be taken as granted.

${ }_{19}$ Whereas most military governments were right-wing, some had a left-wing orientation.

${ }^{20}$ Moreover, a substantial share of these expenditures was largely associated with the conditionality implicit in most international aid donations received by the country (Pereira et al. 2012).

21 This idea certainly contrasts with the conventional wisdom in Bolivia. However, the Bolivian experience is not necessarily an unusual exception in world history. Indeed, the expansion of social spending in Europe took place under both left-wing and right-wing governments (Lindert 2004; Comín 2007). In the same vein, the right-wing military dictatorship in Uruguay did not reverse the expansion of social spending during the 1970s and 1980s (Azar et al. 2009).
} 
The significance of this phenomenon can be better understood by looking at the evolution of social public expenditure in other Latin American countries $(\text { Table } 3)^{22}$. The comparison shows that the share of social spending within total expenditure was smaller in Bolivia than in the rest of countries throughout the first third of the $20^{\text {th }}$ century. Thereafter, the increase in Bolivia closed the gap with both Chilean and Peruvian levels. Moreover, during the 1950s and 1960s, the relative importance of social spending in Bolivia was higher than in Chile. This fact changed from the 1970s onwards, but the relative importance of social spending within total expenditure in Bolivia has remained slightly superior to the Peruvian figure. Nevertheless, it must be noticed that the Bolivian ratio of social spending to GDP did not approach the figures presented in the rest of countries until the 1990s.

Therefore, the comparative perspective suggests that the priority of social spending within total expenditure must not be neglected in the Bolivian case from the 1940s onwards, once it achieved ratios similar to some of the most developed countries in the region. However, it also suggests that the economic impact of this increasing fiscal priority would not necessarily be outstanding given the low level of expenses in relation to the aggregate economy. The presence over long periods of this disparity between a high priority on social spending and scarce resources, introduces different research questions into the debate. The following paragraphs analyse the difficulties faced by successive Bolivian governments in order to finance these increases in social spending by looking at the composition of public revenues.

To start with, Figure 4 presents the composition of public revenues and shows that international trade taxes were the most important revenue from the last quarter of the $19^{\text {th }}$ century to the early $1980 \mathrm{~s}^{23}$. Thus, indirect internal taxes accounted for a significant share of Bolivian public revenues only from the late 1980s onwards. These taxes represent more than half of total current revenue nowadays. Meanwhile, and particularly since 2005, non-tax revenues have become important for both central and general government. By contrast, with the only exception of the 1940s, direct taxes have always had a minor importance and, similarly, social contributions have commonly represented $<10$ per cent of current revenue ${ }^{24}$.

22 Because of data restrictions the comparison considers just three other Latin American cases: Chile, Peru and Uruguay. Despite this limited coverage, these countries may be considered as good references since, for instance, two of them (Chile and Uruguay) were among the earliest supporters of social public expenditure in Latin America (Azar and Fleitas 2012). Argentina, Brazil and Mexico are not considered in the sample since, due to its federal nature, central government statistics may underestimate the size of social spending.

${ }^{23}$ For the composition of each revenue category, see the methodological appendix and IMF (2001, p. 49).

${ }^{24}$ Modern Social Security was introduced in Bolivia through the unification of all social security services in a single unit - the "Caja Nacional de Seguridad Social» - by the Código de Seguridad Social enacted in 14 December 1956 (Aponte et al. 2008). The law fostered an important 
TABLE 3

SOCIAL PUBLIC SPENDING IN LATIN AMERICA AS A SHARE OF CENTRAL GOVERNMENT'S TOTAL EXPENDITURE AND AS A SHARE OF GDP, 1900-2010 (\%, TEN YEAR AVERAGES)

\begin{tabular}{|c|c|c|c|c|c|c|c|c|}
\hline & \multicolumn{2}{|l|}{ Bolivia } & \multicolumn{2}{|l|}{ Chile } & \multicolumn{2}{|l|}{ Peru } & \multicolumn{2}{|c|}{ Uruguay } \\
\hline & $\%$ Expenditures & $\%$ GDP & $\%$ Expenditures & $\% \mathbf{G D P}$ & $\%$ Expenditures & $\%$ GDP & $\%$ Expenditures & $\%$ GDP \\
\hline 1900-1909 & 5.08 & 0.23 & 7.54 & 0.86 & 12.64 & 0.55 & N.a. & N.a. \\
\hline 1910-1919 & 9.57 & 0.49 & 11.34 & 1.03 & 15.31 & 0.71 & 25.28 & 2.82 \\
\hline 1920-1929 & 8.98 & 0.45 & 14.29 & 1.53 & 14.41 & 0.84 & 38.04 & 3.38 \\
\hline 1930-1939 & 9.42 & 0.57 & 20.84 & 2.67 & 15.94 & 1.19 & 44.95 & 5.88 \\
\hline 1940-1949 & 21.04 & 1.33 & 22.88 & 3.28 & 21.89 & 2.21 & 42.92 & 5.48 \\
\hline 1950-1959 & 26.66 & 1.43 & 20.68 & 3.57 & 26.57 & 2.94 & 61.70 & 7.55 \\
\hline 1960-1969 & 30.89 & 2.92 & 24.38 & 5.06 & 34.67 & 5.39 & 63.59 & 7.59 \\
\hline 1970-1979 & 38.84 & 4.55 & 38.52 & 12.51 & 24.52 & 8.71 & 59.12 & 9.56 \\
\hline 1980-1989 & 37.67 & 5.33 & 60.97 & 18.34 & 21.64 & 3.62 & 57.03 & 10.71 \\
\hline 1990-1999 & 43.30 & 9.23 & 60.89 & 12.74 & 39.09 & 5.96 & 67.74 & 12.91 \\
\hline $2000-2010$ & 49.92 & 13.76 & 67.13 & 14.26 & 48.26 & 8.90 & 67.86 & 14.90 \\
\hline
\end{tabular}

Notes: N.a.: Not available.

Sources: See Table 1. 
FIGURE 4

CENTRAL GOVERNMENT'S REVENUE COMPOSITION, 1882-2010 (SHARE OF TOTAL CURRENT REVENUE, \%)

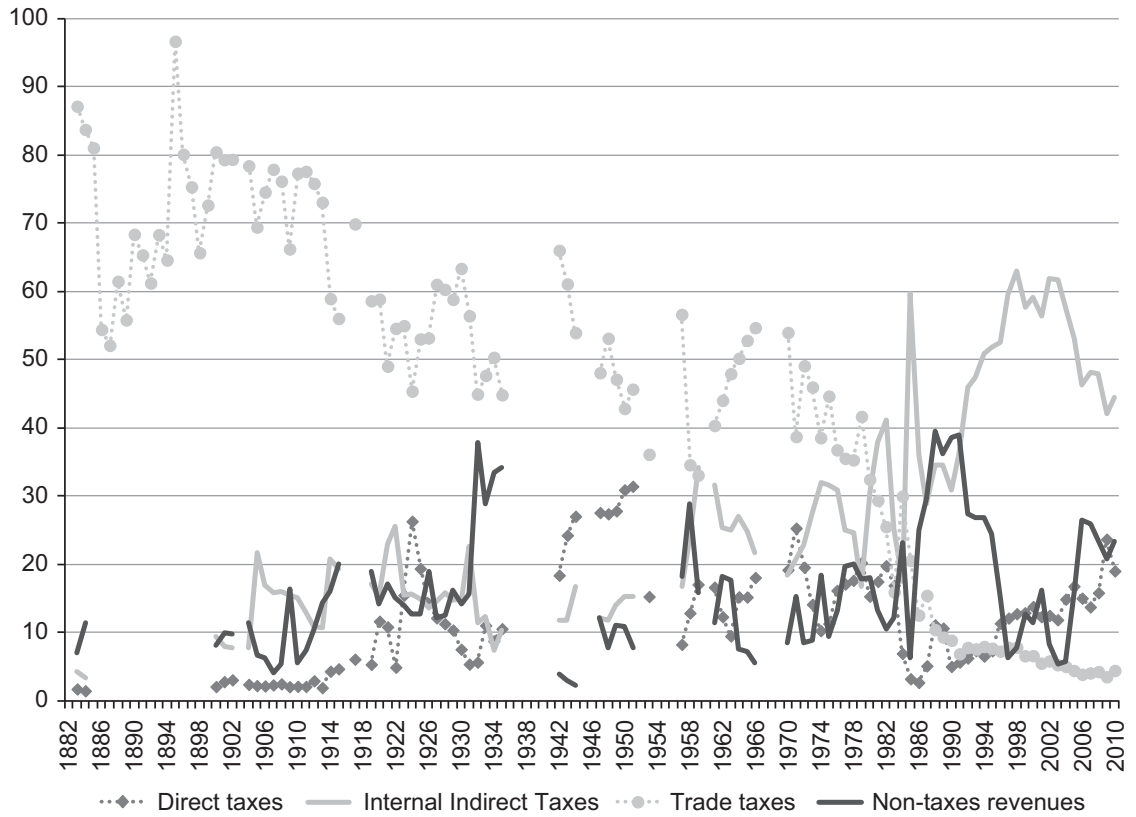

Source: See text.

The centrality of international trade taxes in the history of Bolivian public finances may be highlighted, again, by means of a regional comparison (Table 4). The table confirms that these taxes were the most important revenue in Latin America until the Great Depression (Coatsworth and Williamson 2004). However, it also indicates that there were different patterns of fiscal transition in the region from international trade to indirect internal taxes (Cortés-Conde 2006) $^{25}$. In this context, the Bolivian government's persistent

\footnotetext{
(F'note continued)

increase in the system's coverage (Dirección Nacional de Informaciones 1962; Zondag 1966). Despite this increase, coverage rates remained low; for instance, at the end of the 1980s, the system only covered 20 per cent of total population (Evia and Fernández 2004). This low coverage and the state's inability to collect these revenues (Zondag 1966; Evia and Fernández 2004) explain the low relative importance of social contributions. This conclusion is based on the analysis of the point estimations offered in Dirección Nacional de Informaciones (1962) for the period 1956-1962, and the Social Security revenue series available since 1983 in the IMF statistics.

25 See Steinmo (2003), Cardoso and Lains (2010) and Yun-Casalilla et al. (2012) for the analysis of tax transitions in the case of developed and Asian economies.
} 
TABLE 4

INTERNATIONAL TRADE TAXES IN LATIN AMERICA, 1900-2010 (SHARE OF CENTRAL GOVERNMENT'S CURRENT REVENUE, TEN YEAR AVERAGES)

\begin{tabular}{|l|c|c|c|c|c|c|c|c|}
\hline & Argentina & Brazil & Colombia & Peru & Uruguay & Bolivia & $\begin{array}{c}\text { Costa } \\
\text { Rica }\end{array}$ & Guatemala \\
\hline $1900-1909$ & 49.92 & 52.22 & N.a. & 51.23 & 61.21 & 75.73 & 63.01 & N.a. \\
\hline $1910-1919$ & 46.63 & 43.42 & 64.93 & 40.49 & 53.32 & 68.40 & 52.39 & N.a. \\
\hline $1920-1929$ & 48.88 & 37.68 & 49.89 & 39.83 & 46.64 & 54.91 & 59.21 & N.a. \\
\hline $1930-1939$ & 33.57 & 32.80 & 45.87 & 29.92 & 41.91 & 51.26 & 57.17 & N.a. \\
\hline $1940-1949$ & 13.06 & 14.63 & 23.16 & 29.25 & 29.12 & 54.88 & 41.94 & 38.35 \\
\hline $1950-1959$ & 4.54 & 6.90 & 28.36 & 29.28 & 21.33 & 41.48 & N.a. & 48.48 \\
\hline $1960-1969$ & 2.29 & 7.75 & 25.46 & 20.21 & 27.46 & 48.32 & N.a. & 36.57 \\
\hline $1970-1979$ & 20.84 & 7.22 & 15.92 & 22.91 & 16.18 & 42.02 & N.a. & 31.34 \\
\hline $1980-1989$ & 13.07 & 3.85 & 14.51 & 21.85 & 15.44 & 22.27 & N.a. & 21.93 \\
\hline $1990-1999$ & 5.65 & 1.16 & 10.16 & 9.86 & 7.20 & 7.63 & 11.60 & 17.68 \\
\hline $2000-2010$ & 14.85 & 2.19 & 7.08 & 6.24 & 5.80 & 4.81 & 7.01 & 10.15 \\
\hline
\end{tabular}

Notes: N.a.: Not available.

Sources: (a) Bolivia, see text; (b) Guatemala: ICEFI (2007); (c) Costa Rica from 1900 to 1948 from Román (1995); (d) Rest of countries from 1900 to 2000 and Costa Rica from 1992 to 2000 from MOxLAD database: http://moxlad.fcs.edu.uy/; (e) All countries from 2001 to 2007 from ECLAC database: www.eclac.cl.

dependence on international trade taxes until the early 1980s may be interpreted as an extreme case of the external tax dependence that prevailed in the poorer Latin American economies ${ }^{26}$.

This external dependence, however, was not necessarily based on the same type of taxes over time. Indeed, as in other Latin American cases, I found that export taxes played an important role in several episodes of Bolivian economic history ${ }^{27}$. Thus, between the last quarter of the $19^{\text {th }}$ century and the early 1980s, the Bolivian central government was sometimes dependent on custom duties and sometimes on export taxes.

This distinction is not irrelevant since it implies substantial differences in tax bases. Tax dependence on custom duties made the government rely more closely on those economic agents related with imports which, as in the rest of Latin America, can be broadly identified with urban elites and

26 After the external debt crisis, international trade taxes lost ground throughout the region. The Argentinean case since 2002 is the only major exception to this trend.

27 Export taxes accounted for 40 per cent of international trade taxes from 1883 to 1893 ; for 30 per cent during the 1910s and 1920s; for more than 80 per cent from 1935 to 1956; and, for 30 per cent during the 1970s. Export taxes were eliminated during the late 1980s and early 1990s. 
middle classes. By contrast, given the concentration levels of Bolivian exports, a higher tax dependence on export taxes implied a close fiscal relationship between the Bolivian government and a small number of economic agents. This phenomenon was especially extreme from the early 1930s to the early 1950s, when taxes paid by three «Tin Barons» — which accounted for 75 per cent of Bolivian exports - represented the bulk of Bolivian public revenues ${ }^{28}$.

The identification of the relevant tax bases and taxpayers also provides interesting information in the case of direct taxation. Indeed, according to Gallo (1991, pp. 76-83), thanks to the control of both the Congress and local institutions, landowning elites were able to resist any increase in rural direct taxation throughout the first half of the $20^{\text {th }}$ century ${ }^{29}$. By contrast, during the same period of time, the Bolivian central government tried to consolidate a profit tax on mining activities and, after some failed experiences, this goal was finally achieved in 1923, when, thanks to the pressure of international lenders (Contreras 1990), tax collection increased substantially. Mining producers were later able to reduce tax pressure on their activities (Drake 1989, pp. 205-206; Gallo 1991, pp. 108-109) and, as a consequence, the relative importance of direct taxation returned to the levels it had before the fiscal reform of 1923. Direct taxes increased again in the 1940s and, regardless of the conservative or progressive nature of Bolivian governments, became the second most important revenue source throughout that decade. These taxes, however, came overwhelmingly from very specific sources - mining and bank utilities - and, therefore, did not necessarily represent an expansion of the social groups that constituted the main government's tax bases ${ }^{30}$.

Tax bases were also rather narrow in the case of indirect internal taxes. Indeed, until the late 1920s there was no general consumption tax and all indirect internal taxes were excises. Most of these were obtained from specific agents or economic flows and, therefore, their individual contribution to total revenues was negligible; most of the time smaller than 1 per cent of total current revenue (Mc Queen 1925, p. 36). Likewise, the new excises created during the 1930s and 1940s did not increase the relative importance of indirect internal taxes but the complexity of a system that was criticised

${ }^{28}$ Considering the elasticity of tin exports (Gómez 1978), the share of Bolivian exports in the tin market (Peñaloza 1985) and the evolution of international prices, it may be assumed that tin producers could not transfer additional tax pressures to international consumers (Gutiérrez Guerra 1940, pp. 88-93; Pando 1941, p. 62; Banco Minero de Bolivia 1941, p. XXVI; Gallo 1991, pp. 97-118).

29 At least until the early 1920s, the responsibility for the regulation of direct taxation was partially in the hands of departments and municipalities (Mc Queen 1925, pp. 83-84).

30 The lack of detailed information prevents any analysis of the nature of Bolivian direct taxes during the 1950s and 1960s. During the 1970s, direct taxation increased again thanks to the increase in income taxes both from individuals and companies (UDAPE 1985, pp. 11-13), but its relative importance remained below that of indirect international trade and internal taxes. 
for the high number of different and marginal taxes (Banco Minero de Bolivia 1941, pp. XX-XXIII, Pando 1941, p. 1). Excises still represented the bulk of indirect internal taxes from the 1950s to the early 1980s, although their contribution to total revenues increased since the early 1970s thanks to the rationalisation of the system (UDAPE 1985, pp. 69-87). In any case, the prevalence of excise taxes during most of the $20^{\text {th }}$ century would indicate that Bolivian governments' ability to levy taxes internally was limited to some easily identifiable economic activities (Gallo 1991, p. 100; Barragán and Peres-Cajías 2007, pp. 140-146).

Indirect internal taxation did not represent a clear alternative to international trade taxes until the 1986 tax reform which established a new system with fewer taxes but broader tax bases (Otálora 1995, p. 113; Pereira et al. 2012, pp. 57-59). Indeed, driven by the consolidation of a new value added tax, the tax reform ushered in the transition from a fiscal system based on external trade taxes to a new one mainly financed through indirect internal taxes. This process, in turn, made it possible to increase public revenues and reduce volatility; two achievements which were further consolidated by different reforms aimed at improving tax administration (Pereira et al. 2012, pp. 74, 113-121).

Meanwhile, taxes and non-tax revenues coming from oil and gas activities have gained a critical new role in Bolivian public finances. On the one hand, non-tax revenues from oil and gas production were vital for the initial recovery of the government's revenues in 1986, when the price of gasoline was increased by 833 per cent and a transfer scheme from "Yacimientos Petrolíferos Fiscales Bolivianos» to the central government was established (Pereira et al. 2012, p. 57). On the other hand, the increasing relevance of several taxes on oil and gas activities, which were established when the sector was privatised in the 1990s - the 1194 Law in 1990, and the Impuesto Especial a los Hidrocarburos in 1994 - made it possible to use the domestic price of gasoline as an instrument to curb budget deficits - the so-called gasolinazos (Pereira et al., 2012, pp. 62, 74-76, 107). Finally, the new law on gas and oil activities enacted in May 2005 introduced the Impuesto Directo a los Hidrocarburos and increased the oil and gas tax burden to 50 per cent of total production (Pereira et al., 2012, p. 111).

Therefore, whereas the extreme dependence of Bolivian public finances on narrow revenue bases has been partially reduced since the mid-1980s, the relevance acquired recently by taxes and non-tax revenues coming from oil and gas activities has stopped this process. The importance of this phenomenon may not be negligible since, as is further explored in the next section, an extreme dependence on specific revenues may increase the vulnerability of state intervention to external shocks which, in turn, may generate negative externalities on the rest of the economy and reduce the potential redistributive impact of social spending. 


\section{A FIRST ASSESSMENT OF BOLIVIAN PUBLIC FINANCES: A MACROECONOMIC PERSPECTIVE}

The analysis of budget deficits may be taken as a first indication of the vulnerability of Bolivian public finances throughout the period under study. Since the database does not consider transactions in non-financial and financial assets and liabilities, here, strictly speaking it is not possible to use the standard definition of budget deficit. However, the database allows us to approximate the evolution of the operating balance. This figure indicates the extent to which current revenue can finance total expenditure and constitutes "a summary measure of the ongoing sustainability of government operations» (IMF 2001, p. 38) ${ }^{31}$. In this regard, the Bolivian data show that, on average, current revenue could only cover 80 per cent of total spending. Actually, in some periods, the gap between both variables was significantly higher than 20 per cent $(1919-1922 ; 1944-1953 ; 2000-2004)$ or even 40 per cent (1932-1935; 1979-1985) (Figure 5).

It was not until the end of the First World War when budget deficits became particularly large and could not be covered by internal borrowing (Mc Queen 1925; Huber 2001). The widening of the budget gap resulted from the expansion of expenditures and the stagnation of revenues derived from the 1920-1922 export crisis. In this context, the Bolivian central government had to resort to external borrowing, among other policies, and obtained the Stiefel Nicolaus loan (US\$29 million) in 1922 in order to close its fiscal gap.

Meanwhile, in order to ensure repayment of the debt, international lenders required a major fiscal reform. This was enacted in 1923 and implied both an increase in the tax rate of international trade taxes and the creation of new taxes on other activities (Mc Queen 1925). International lenders also asked for the control of those sources of public revenues that were pledged to repayment of the debt through the formation of the «Fiscal Permanent Commission» (Contreras 1990). While these fiscal changes represented a clear undermining of Bolivian state sovereignty, they made it possible for central government revenues to increase from 2.5 per cent of GDP in 1922 to 5 per cent between 1924 and 1929.

Given the government's dependence on indirect external taxes, the 1929 external shock made Bolivian public finances unsustainable and current revenues fell in 1931 to just 2.8 per cent of GDP. However, expenditures were more rigid and, as a consequence, budget deficits widened. Because of these fiscal troubles and the closure of international capital markets, the Bolivian government had no option but to default on its external debt payments in

31 Revenues less expenses equal the operating balance. According to the IMF (2001, p. 38) framework, revenues are composed of taxes, social contributions, other revenues and donations. Because of data scarcity, the present document ignores the last category in the estimation of the Bolivian operating balance. 
FIGURE 5

CENTRAL GOVERNMENT AND GENERAL GOVERNMENT OPERATING BALANCES, 1900-2010 (SHARE OF TOTAL EXPENDITURE, \%)

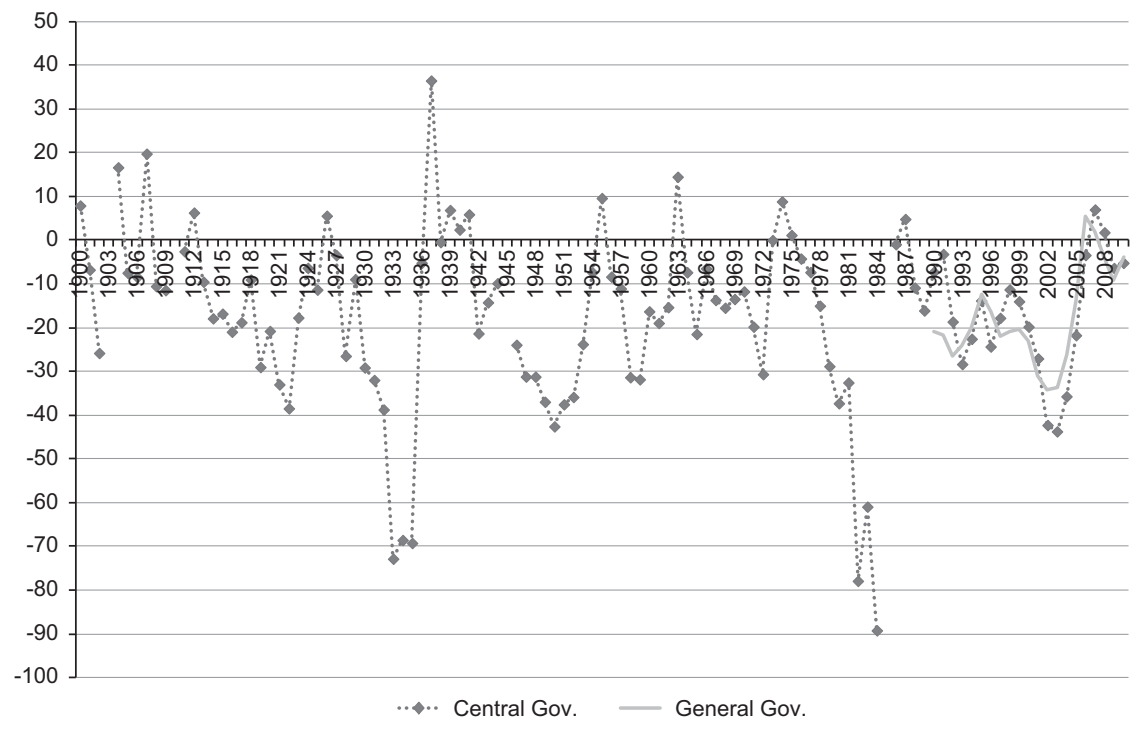

Source: See text.

September 1931. One year later, defense expenditure rose because of the Chaco War and total expenditure reached 8 per cent of GDP in 1933. In order to finance these additional expenditures, the government increased the fiscal burden on the mining sector ${ }^{32}$. These measures, however, were insufficient and the government had to resort to internal borrowing from the recently created Bolivian Central Bank (1928). This last measure had a clear incidence on inflation rates, which remained around 25 per cent yearly from 1932 to 1935.

The Military-Socialist regimes tried to maintain a high fiscal burden on mining activities. To this end, they confirmed the special tax laws enacted

32 For instance, thanks to the reorganisation of the tin market after the crisis, it could obtain loans from mining producers (Contreras 1990; Gallo 1991, p. 44). It also imposed new taxes on mining, which were justified by war efforts (Banco Minero de Bolivia 1941, p. XVIII). Furthermore, the state established a new heterodox tax: «the control of foreign exchange». Mining producers were forced to sell the state a share of their foreign exchange gains at an overvalued exchange rate. Selling these foreign currencies at market rates, the state obtained a seigniorage gain. This implicit tax gained importance at the end of 1934, when the share of the foreign exchange gains that had to be sold to the government was increased to 42 per cent and the difference between official and market exchange rates was widened (CEPAL 1958, p. 34). 
during the Chaco War, and also increased the rates on the foreign exchange tax. Moreover, in June 1939, President German Busch decreed that mining producers had to sell 100 per cent of their foreign exchange gains to the government. President Busch committed suicide after some difficulties in the implementation of the new tax rate and the measure was short-lived. However, the Bolivian government's attitude towards mining producers did not change and the mandatory sale of foreign exchange gains and high export tax rates for the mining sector continued to be one of the most salient features of Bolivian tax policy during the 1940s (CEPAL 1958, pp. 33-35; Gallo, 1991, pp. 123-128).

This policy was reinforced by the Bolivian economy's inability to increase its food production and the growing political relevance of poor urban consumers, which provoked the reduction of tariffs on foodstuff and, because of their relative importance on total imports, of overall import taxes (Gallo 1991, pp. 67-74). Nevertheless, the increasing fiscal burden on mining activities was not always sufficient to compensate this reduction and total current revenues were sometimes insufficient to cover total expenditures. As a consequence, the Bolivian government often had to rely on loans from the Central Bank which made domestic price levels climb.

During the initial years of the revolution (1952-1956), the new leaders had to confront the same fiscal dilemma that had been faced by former Bolivian governments: how to raise public revenues in the short run in order to curb growing political demands. The solution, once again, did not vary in relation with previous experience and the government applied a multiple exchange rate regime to take advantage of the foreign exchange gains made by the mining sector (Gómez 1978). The measure had some positive effects. For instance, thanks to the reallocation of mining foreign exchange gains, Bolivia completed a process of oil import substitution by 1954 (Zondag 1966). However, it also sharply reduced the revenues of the new public mining company («Corporación Minera de Bolivia», COMIBOL) while its expenditures were growing rapidly. Indeed, the new government decided that COMIBOL had to increase social contributions to its employees and had to hire all those miners who had lost their jobs during the 1950-1951 mining crisis (Zondag 1966). As a consequence, COMIBOL ran into increasing losses, which were paid by the central government with loans from the Bolivian Central Bank ${ }^{33}$. These decisions, once more, had clear macroeconomic effects: yearly inflation soared to 245 per cent in 1953 and remained around 100 per cent in 1954, 1955 and 1956.

Under this critical situation, the revolutionary government - in close collaboration with the IMF and the United States - implemented an aggressive Stabilization Plan at the end of 1956, involving the removal of

${ }^{33}$ For example, between 63 per cent and 85 per cent of all state obligations in the Central Bank came from the mining sector from 1952 to 1956 (CEPAL 1958, pp. 70-71). 
previous policies and a new tax reform. The restoration of macroeconomic stability and the tax reform led to a spurt in current public revenues, but budget deficits persisted. This time, however, these were financed through U.S. donations, which represented 25 per cent of the current plus capital revenues of the Bolivian government (Wilkie 1969) ${ }^{34}$. Moreover, the support of the United States involved the renegotiation of the external debt service and allowed a new access to international capital markets (Pacheco 2001). Therefore, budget deficits in the 1960s were financed through U.S. donations initially and through long-term bilateral credits thereafter (Pacheco 2001), which made it possible to control the evolution of price levels.

During the 1970s, external borrowing grew massively (Villegas 2001) and, despite some tax diversification, Bolivian public revenues were still dependent on international trade taxes. Hence, not surprisingly, external shocks led to dramatic fiscal changes. To start with, the fall in tin exports from 1978 to 1981 (Luna 1995, pp. 152-155) generated a reduction in current public revenues from 11 per cent to 9 per cent of GDP. This reduction was not followed by a similar reduction in expenditure because of its rigidity. Then, the rise in global interest rates and the maturity of most commercial external credits led to an increase in external debt payments (Otálora 1995, p. 122). Thus, budget deficits widened and, by 1981, current revenues could only finance 67 per cent of expenditures.

The fiscal gap became unsustainable from 1982 onwards, when Bolivia lost the possibility of borrowing from international capital markets. As a consequence, the government financed the gap again with internal borrowing from the Bolivian Central Bank (Morales and Sachs 1990) and, as a result, yearly inflation soared to 123 per cent. One year later, current public revenues fell to just 4 per cent of GDP because of a new reduction in tin exports and the Olivera-Tanzi effect on public revenues (Otálora 1995, pp. 96-101). Furthermore, the return of democracy in 1982 fuelled an important increase in political demands. For instance, in order to compensate for inflation losses, public employees asked for wage increases. Given the political fragility of the government, this request - among others - was accepted. Together with the increase in external debt payments, these measures raised government expenditure to 30 per cent of GDP in 1984. The government's short-term solution was both to spend the international reserves and to ask for additional Central Bank loans, but the consequence was hyperinflation: from May 1984 to September 1985 the annual variation of prices was around 1,700 per cent, one of the highest figures in world history.

34 The interest of the U.S. government in the fiscal sustainability of the Bolivian government must be understood in the context of the Cold War and the U.S. efforts to discard the transition of the 1952 revolution from its nationalist scheme to a communist one. U.S. donations to Bolivia from 1958 to 1964 were, in per capita terms, six times higher than the amount provided to Bolivia's neighbouring countries (Sandoval et al. 2003, pp. 63-67). 
Despite important recent improvements in the tax system, budget deficits and the sustainability of public finances have remained as great concerns for Bolivia during the last decades. Indeed, the 1996 pension reform had a great impact on government expenditures - around 4 per cent of GDP according to Pereira et al. (2012) — which, in combination with the economic stagnation provoked by the Asian recession, brought about a new episode of fiscal crisis at the beginning of the 2000s. This crisis, however, did not foster other macroeconomic imbalances thanks to sounder fiscal and monetary policies and the funding of the fiscal gap through donations and external credits ${ }^{35}$.

\section{CONCLUSION}

Especially after the defeat in the Chaco War (1932-1935), the relative importance of social public expenditure within total spending has tended to increase constantly in Bolivia. Meanwhile, there has been a tendency to finance these expenses through the expansion of very specific sources of revenues, especially international trade taxes and revenues obtained from the exploitation of natural resources. Most of the time, these revenues have been insufficient and, as a consequence, Bolivian governments have presented constant and chronic budget deficits. This fiscal gap could initially be financed with external resources, either external borrowing or donations. However, when these were unavailable, the Bolivian government resorted to credits from the Bolivian Central Bank. This solution fostered several macroeconomic unbalances, of which the hyperinflation process is by far the most salient example.

Bolivian public finances have constructed a more solid base during the last decades. Indeed, the fiscal reform of 1986 made it possible to increase tax bases which, in turn, allowed increasing current revenues and converging steadily and smoothly with the Latin American average. Whereas these achievements may bring more resources to face the fiscal priorities of the Bolivian government some caution is still needed. Specifically, the recent dependence on oil and gas taxes may increase the vulnerability of the system to external shocks which, as has been proved in this paper, may have important negative consequences on the rest of the economy.

\section{REFERENCES}

Aponte, G.; Ferrufino, R., Jemio, L. C., and Urioste, J. C. (2008): Pensiones y jubilación en Bolivia. La Paz: Fundación Milenio.

35 Internal borrowing had acquired some relevance during the late 1990s, but did not come from the Central Bank. See Villegas (2001), Pereira et al. (2012) and the «Public debt database» at the Fundación Jubileo web site: http://www.jubileobolivia.org.bo/deuda. 
Azar, P.; Bertino, M., Bertoni, R., Fleitas, S., Garcia, U., Sanguinetti, C., Sienra, M., and Torelli, M. (2009): ¿De quiénes, para quiénes y para qué: las finanzas públicas en el Uruguay del siglo XX. Montevideo: Fin de Siglo.

Azar, P., and Fleitas, S. (2012): «Gasto Publico Total y Social: El Caso De Uruguay En El Siglo XX». Revista de Historia Económica 30, pp. 125-156.

Banco Minero De Bolivia (1941): Tasas e impuestos sobre la industria minera en Bolivia. La Paz: Banco Minero De Bolivia.

Barragán, R. (2007): Las asambleas constituyentes en Bolivia. La Paz: Defensor del Pueblo.

Barragán, R., and Peres-Cajías, J. A. (2007): «El armazón estatal y sus imaginarios. Historia del Estado», in Udape (ed.), Informe Nacional de Desarrollo Humano 2007. El Estado del Estado. La Paz: PNUD, pp. 127-218.

Bordo, M., and Cortés-Conde, R. (2001): Transferring Wealth and Power from the Old to the New World: Monetary and Fiscal Institutions in the 17th Through the 19th Centuries. Cambridge: Cambridge University Press.

Brautigam, D.; Fueldstad, O., and Moore, M. (2008): Taxation and State-Building in Developing Countries: Capacity and Consent. Cambridge: Cambridge University Press.

Breceda, K.; Rigolini, J., and SaAvedra, J. (2009): «Latin America and the Social Contract: Patterns of Social Spending and Taxation». Population and Development Review 35, pp. 721-748.

Candia, F.; Evia, J. L.; Ferrrufino, R., Gavincha, M., Jemio, L. C., Laserna, S., Medinaceli, M., and Velásouez, I. (2013): Gasto Fiscal y Bien Común. La Paz: Fundación Milenio.

CAJÍAs, M. (2011): Continuidades y rupturas: el proceso histórico de la formación docente rural y urbana en Bolivia. La Paz: PIEB.

Cardoso, J. L., and Lains, P. (2010): Paying for the Liberal State: The Rise of Public Finance in Nineteenth-Century Europe. Cambridge: Cambridge University Press.

CEPAL. (1958): Análisis y proyecciones del desarrollo económico. IV. El desarrollo económico de Bolivia. México: Naciones Unidas, Departamento de Asuntos Económicos y Sociales.

CEPAL. (2010): La hora de la igualdad: brechas por cerrar, caminos por abrir. Santiago: CEPAL.

Coatsworth, J. H., and Williamson, J. G. (2004): «Always Protectionist? Latin American Tariffs from Independence to Great Depression». Journal of Latin American Studies 36, pp. 205-232.

Comín, F. (2007): «El Surgimiento y Desarrollo del Estado Del Bienestar (1883-1980)», in S. Salort and R. Muñoz (eds), El Estado Del Bienestar en La Encrucijada. Alicante: Publicaciones de la Universidad de Alicante, pp. 67-128.

Comín, F., and Díaz-Fuentes, D. (2007): «De una Hacienda Imperial a dos Haciendas Nacionales. Las Reformas Tributarias en México y España durante El Siglo XIX», in R. Dobado; A. Gómez-Galvarriato, and G. Márquez (eds), México y España. ¿Historias Económicas Paralelas? México, D.F.: El Trimestre Económico/ Fondo de Cultura Económica, pp. 185-250.

Contreras, M. E. (1990): «Debt, Taxes, and War: the Political Economy of Bolivia, c. 1920-1935». Journal of Latin American Studies 22, pp. 265-287.

Cortés Conde, R. (2006): «Fiscal and Monetary Regimes», in V. Bulmer-Thomas; J. H. Coatsworth and R. Cortés Conde (eds), The Cambridge Economic History of Latin America. Cambridge: Cambridge University Press, pp. 209-248.

Del Granado, H.; Mokrani, L., Medinaceli, M., and Gumucio, J. (2010): Investigación Sobre la Generación, Distribución y Uso Del Excedente Proveniente de la Explotación de Los Hidrocarburos En Bolivia. La Paz: PIEB. 
Delgadillo, H. (2001): «Apéndice Estadístico», in H. Huber Abendroth; N. Pacheco; C. Villegas; Á. Aguirre, and H. Delgadillo (eds), La deuda externa de Bolivia - 125 años de renegociaciones y cuantos más?: desde la operación secreta del gobierno y los Meiggs hasta la iniciativa HIPC. La Paz: CEDLA/OXFAM, pp. 401-539.

DíAz-Fuentes, D. (1999): «Models of Growth and Fiscal Policy in Latin America: Fiscal Dependence on Foreign Trade and Tax Reforms in the Interwar Period", in F. Comín; D. Díaz-Fuentes, and E. Schremmer (eds), Tax Systems in Historical Perspective: Equity or Growth? Madrid: Instituto Complutense de Estudios Internacionales, pp. 35-50.

Dirección Nacional De Informaciones. (1962): Bolivia: 10 años de revolución 1952-1962. La Paz: Dirección Nacional De Informaciones.

DraKe, P. W. (1989): The Money Doctor in The Andes: The Kemmerer Missions, 1923-1933. Durham: Duke University Press.

Dunkerley, J. (2003): «The Origins of the Bolivian Revolution in the 20th Century: Some Reflections», in M. Grindle and P. Domingo (eds), Proclaiming Revolution: Bolivia in Comparative Perspective. London: Institute of Latin American Studies, pp. 135-163.

Engel, E.; Galetovic, A., and Raddatz, C. (1999): "Taxes and Income Distribution in Chile: Some Unpleasant Redistributive Arithmetic». Journal of Development Economics 59, pp. 155-192.

Evia, J. L., and Fernández, M. (2004): «Reforma de Pensiones y valoración del seguro social de largo plazo en Bolivia». Documento de Trabajo IISEC 02/04, pp. 1-35.

FundaCión Jubileo. (2011): Análisis de Ingresos por Regalías y Participaciones Hidrocarburiferas. La Paz: OXFAM/Fundación Jubileo.

Fundación Jubileo. (2012a): «Renta Hidrocarburífera. Más allá de las Regalías y del IDH». Serie Debate Público No. 24, pp. 1-32.

Fundación Jubileo. (2012b): «Volatilidad de Ingresos por Hidrocarburos». Serie Debate Público No. 25, pp. 1-27.

Fundación Jubileo. (2013): «Situación de los Hidrocarburos en Bolivia». Serie Debate Público No. 27, pp. 1-16.

Gallo, C. (1991): Taxes and State Power: Political Instability in Bolivia, 1900-1950. Philadelphia: Temple University Press.

Gamarra, M. P. (2007): Amazonía Norte de Bolivia, economía gomera (1870-1940). Bases económicas de un poder regional. La casa Suárez. La Paz: CIMA.

Gómez, W. (1978): La minería en el desarrollo económico de Bolivia, 1900-1970. La Paz: Editorial Los Amigos del Libro.

GoÑI, E.; López, J. H., and ServéN, L. (2011): «Fiscal Redistribution and Income Inequality in Latin America». World Development 39, pp. 1558-1569.

Gutiérrez Guerra, R. (1940): Situación Económica y Financiera de Bolivia. La Paz: Asociación de Industriales Mineros.

Guzmán, J. C.; Crespo, M., Gemucio, T., and Gadea, C. (2010): Uso Productivo Del Excedente Hidrocarburífero. Propuesta de Creación Del Fondo Soberano de Las Regiones. La Paz: PIEB.

Herranz, A., and Peres-CaJias, J. A. (2013): «Tracing the Reversal of Fortune in the Americas: Bolivian GDP Per Capita Since the Mid-Nineteenth Century». Paper presented at the European Historical Economics Society Conference, London (September 6-7).

Hinojosa, L. (2012): «Desafiando La Maldición de Los Recursos En Tarija: Pobreza y Política Social Financiada Por Las Rentas de Hidrocarburos», in L. Hinojosa (ed), Gas y Desarrollo. Dinámicas Territoriales Rurales En Tarija - Bolivia. La Paz: CER-DET/Fundación Tierra, pp. 171-195. 
Huber, H. (2001): «La deuda pública externa y sus renegociaciones entre 1875 y el arreglo Ad Referéndum de 1948", in H. Huber Abendroth; N. Pacheco; C. Villegas; Á. Aguirre, and H. Delgadillo (eds), La deuda externa de Bolivia - 125 años de renegociaciones y cuantos más?: desde la operación secreta del gobierno y los Meiggs hasta la iniciativa HIPC. La Paz: CEDLA/OXFAM, pp. 25-193.

ICEFI. (2007): Historia de la Tributación en Guatemala (desde los Mayas hasta la actualidad). Ciudad de Guatemala: ICEFI.

IMF. (2001): Government Finance Statistics Manual 2001. Washington: International Monetary Fund.

Jáuregui, L. (2003): «Vino Viejo y Odres Nuevos. La Historia Fiscal En México». Historia Mexicana LII 3, pp. 725-771.

Junguito, R., and Rincón, H. (2004): «Fiscal Policy in Twentieth-Century Colombia: a Global Vision». Coyuntura Económica XXXIV, pp. 53-75.

Kalmanovitz, S. (ed.). (2011): Nueva Historia Económica de Colombia. Bogotá: Taurus.

KLeIn, H. S. (2011): A Concise History of Bolivia. New York: Cambridge University Press.

Lamb, M. (ed.). (2005): Taxation: An Interdisciplinary Approach to Research. Oxford: Oxford University Press.

Lindert, P. H. (2004): Growing Public: Social Spending and Economic Growth Since the Eighteenth Century. Cambridge: Cambridge University Press.

LunA, J. (1995): «El sector productivo boliviano durante el período inflacionario», in J. A. Morales and G. La Torre (eds), Inflación, estabilización y crecimiento. La experiencia boliviana de 1982 a 1993. La Paz: IISEC/UCB, pp. 143-243.

Mc Queen, C. (1925): Bolivian Public Finance. Washington: Department of State.

Medinaceli, M. (2012): «El sector Hidrocarburos en Bolivia». Policy Papers Friedrich Ebert Stiftung 2, pp. 1-33.

Morales, J. A., and SAchs, J. D. (1990): «Bolivia's economic crisis», in J. Sachs (ed.), Developing Country Debt and Economic Performance, Volume 2. Country studies: Argentina, Bolivia, Brazil, Mexico. Chicago: The University of Chicago Press, pp. 157-268.

OTÁLORA, C. R. (1995): «La Política Fiscal Boliviana entre 1975 y 1989», in J.A. Morales and G. La Torre (eds), Inflación, estabilización y crecimiento. La experiencia boliviana de 1982 a 1993. La Paz: IISEC/UCB, pp. 83-141.

Pacheco, N. (2001): «Deuda externa boliviana entre 1950 y 1970: resolución de las obligaciones», in H. Huber Abendroth; N. Pacheco; C. Villegas; Á. Aguirre, and H. Delgadillo (eds), La deuda externa de Bolivia-125 años de renegociaciones y cuantos más?: desde la operación secreta del gobierno y los Meiggs hasta la iniciativa HIPC. La Paz: CEDLA/OXFAM, pp. 195-270.

Palenoue, J. (1933): «Análisis numérico del presupuesto nacional», in Estadística Boliviana. Primera Parte. Años 1911-1931. La Paz: Talleres Gráficos Renacimiento.

Pando, J. (1941): Crítica de los principales impuestos directos en Bolivia. La Paz: Fénix.

Paz, V.; Gray, G., Jiménez, W., and YáÑez, E. (2013): «Explaining low redistributive impact in Bolivia». Commitment to Equity Working Paper No. 6, Tulane University.

Peñaloza, L. (1985): Nueva historia económica de Bolivia. El estaño. La Paz: Los Amigos del Libro.

Pereira, R.; SherifF, H. E., and Salinas, V. (2012): Finanzas públicas: comportamiento e impacto en el desarrollo nacional y regional (1990-2010). La Paz: PIEB.

Platt, T. (1982): Estado boliviano y ayllu andino: tierra y tributo en el norte de Potosí. Lima: Instituto de Estudios Peruanos.

PNUD. (2010): Los cambios detrás del cambio: desigualdades y movilidad social en Bolivia. La Paz: PNUD. 
Portocarrero, F.; Beltrán, A., and Romero, M. E. (1992): Compendio estadístico del Perú, 1900-1990. Lima: Universidad del Pacífico, Centro de Investigación CIUP.

Román, A. C. (1995): Las finanzas públicas de Costa Rica: metodología y fuentes (1870-1948). San José: Centro de Investigaciones Históricas de América Central.

Sánchez-SAntiró, E. (2011): «El peso de la fiscalidad sobre la Economía Mexicana, 1790-1910». Historia Mexicana 61 (1), pp. 107-162.

Sandoval, C.; Sandoval, A., Del Rio, M. A., Sandoval, F., Mertens, C., and Parada, C. (2003): Santa Cruz: economía y poder, 1952-1993. La Paz: PIEB.

Sokoloff, K. L., and Zolt, E. (2006): «Inequality and Taxation: Evidence from the Americas on How Inequality May Influence Tax Institutions». Tax Law Review 59, pp. 1-76.

Steinmo, S. (2003): «The Evolution of Policy Ideas: Tax Policy in the 20th Century». British Journal of Politics and International Relations 5 (2), pp. 206-236.

TopiK, S. (1987): The Political Economy of the Brazilian State, 1889-1930. Austin: University of Texas Press.

VILLEGas, C. (2001): «Negociación de la deuda externa en el último tercio del siglo XX», in H. Huber Abendroth; N. Pacheco; C. Villegas; Á. Aguirre, and H. Delgadillo (eds), La deuda externa de Bolivia-125 años de renegociaciones y cuantos más? : desde la operación secreta del gobierno y los Meiggs hasta la iniciativa HIPC. La Paz: CEDLA/ OXFAM, pp. 271-334.

WAGNER, G.; Jofré, J., and LÜDERS, R. (2000): «Economía Chilena, 1810-1995. Cuentas fiscales». Documento de Trabajo Instituto de Economía Universidad Católica 188, pp. 1-583.

Wilkie, J. W. (1969): The Bolivian Revolution and U.S. Aid since 1952; Financial Background and Context of Political Decisions. Los Angeles: Latin American Center, University of California.

Williamson, J. (2004): The Washington Consensus as Policy prescription for Development. Washington: World Bank.

Yun-Casalilla, B.; O'Brien, P., and Comín, F. (eds.). (2012): The Rise of Fiscal States: A Global History, 1500-1914. Cambridge: Cambridge University Press.

Zondag, C. H. (1966): The Bolivian Economy, 1952-65 the Revolution and its Aftermath. New York: Praeger. 


\begin{tabular}{|c|c|c|c|c|c|c|}
\hline \multicolumn{7}{|c|}{$\begin{array}{l}\text { TABLE A1 } \\
\text { TOTAL CURRENT REVENUES AND RELATIVE IMPORTANCE OF THE MAIN REVENUE CATEGORIES, } 1882-2010 \\
\text { (FIVE YEAR AVERAGES) }\end{array}$} \\
\hline & Currency & $\begin{array}{l}\text { Current } \\
\text { revenues }\end{array}$ & $\begin{array}{c}\text { Direct } \\
\text { taxes }(\%)\end{array}$ & $\begin{array}{l}\text { Internal indirect } \\
\text { taxes }(\%)\end{array}$ & $\begin{array}{c}\text { International trade } \\
\text { taxes }(\%)\end{array}$ & $\begin{array}{c}\text { Non-tax } \\
\text { revenues (\%) }\end{array}$ \\
\hline $1882-84$ & Bolivianos & $2,077,531$ & 1.60 & 3.82 & 85.42 & 9.17 \\
\hline $1885-89$ & Bolivianos & $4,182,402$ & N.a. & N.a. & 60.96 & N.a. \\
\hline $1890-94$ & Bolivianos & $3,834,294$ & N.a. & N.a. & 65.56 & N.a. \\
\hline $1895-99$ & Bolivianos & $4,988,490$ & N.a. & N.a. & 78.06 & N.a. \\
\hline $1900-04$ & Bolivianos & $6,231,672$ & 2.59 & 8.23 & 79.36 & 9.82 \\
\hline 1905-09 & Bolivianos & $10,974,838$ & 2.25 & 17.16 & 72.84 & 7.75 \\
\hline $1910-14$ & Bolivianos & $17,505,247$ & 2.68 & 14.08 & 72.53 & 10.71 \\
\hline 1915-19 & Bolivianos & $20,603,874$ & 5.37 & 15.18 & 61.50 & 17.94 \\
\hline $1920-24$ & Bolivianos & $29,077,922$ & 13.84 & 18.98 & 52.56 & 14.62 \\
\hline $1925-29$ & Bolivianos & $44,972,604$ & 13.48 & 14.75 & 57.26 & 14.51 \\
\hline $1930-34$ & Bolivianos & $29,117,605$ & 7.68 & 13.77 & 52.54 & 26.00 \\
\hline $1935-39$ & Bolivianos & $255,473,545$ & N.a. & N.a. & N.a. & N.a. \\
\hline $1940-44$ & Bolivianos & $953,698,488$ & 23.23 & 13.42 & 60.34 & 3.02 \\
\hline $1945-49$ & Bolivianos & $1,206,003,000$ & 27.60 & 12.65 & 49.43 & 10.32 \\
\hline $1950-54$ & Bolivianos & $5,945,962,800$ & N.a. & N.a. & N.a. & N.a. \\
\hline $1955-59$ & Bolivianos & $164,940,000,000$ & 12.73 & 24.89 & 41.42 & 20.95 \\
\hline
\end{tabular}


TABLE A1 (Cont.)

\begin{tabular}{|c|c|c|c|c|c|c|}
\hline & Currency & $\begin{array}{l}\text { Current } \\
\text { revenues }\end{array}$ & $\begin{array}{c}\text { Direct } \\
\operatorname{taxes}(\%)\end{array}$ & $\begin{array}{c}\text { Internal indirect } \\
\text { taxes }(\%)\end{array}$ & $\begin{array}{c}\text { International trade } \\
\text { taxes }(\%)\end{array}$ & $\begin{array}{c}\text { Non-tax } \\
\text { revenues }(\%)\end{array}$ \\
\hline 1960-64 & Bolivianos & $437,340,000,000$ & 13.42 & 27.27 & 45.61 & 13.69 \\
\hline $1965-69$ & Pesos Bolivianos & $777,160,000$ & 16.63 & 23.24 & 53.74 & 6.39 \\
\hline $1970-74$ & Pesos Bolivianos & $2,206,191,200$ & 17.69 & 24.26 & 45.26 & 11.89 \\
\hline $1975-79$ & Pesos Bolivianos & $7,393,000,000$ & 16.50 & 25.77 & 38.78 & 16.04 \\
\hline $1980-84$ & Pesos Bolivianos & $170,280,000,000$ & 15.29 & 30.41 & 26.65 & 15.42 \\
\hline $1985-89$ & Bolivianos & $1,073,100,000$ & 6.56 & 38.68 & 13.66 & 27.33 \\
\hline 1990-94 & Bolivianos & $3,652,650,704$ & 6.17 & 42.21 & 7.82 & 31.71 \\
\hline 1995-99 & Bolivianos & $7,745,836,400$ & 11.29 & 56.85 & 7.44 & 13.31 \\
\hline 2000-04 & Bolivianos & $10,833,541,800$ & 13.08 & 59.27 & 5.65 & 9.44 \\
\hline $2005-10$ & Bolivianos & $28,319,785,671$ & 17.35 & 46.97 & 4.11 & 22.65 \\
\hline
\end{tabular}


TABLE A2

TOTAL EXPENDITURES AND RELATIVE IMPORTANCE OF THE MAIN EXPENDITURE CATEGORIES, 1900-2010 (FIVE YEAR AVERAGES)

\begin{tabular}{|c|c|c|c|c|c|c|c|c|c|}
\hline & Currency & $\begin{array}{c}\text { Total } \\
\text { expenditures }\end{array}$ & $\begin{array}{c}\text { General } \\
\text { public } \\
\text { services } \\
(\%)\end{array}$ & $\begin{array}{c}\text { Public debt } \\
\text { transactions } \\
(\%)\end{array}$ & $\begin{array}{c}\text { Public } \\
\text { order } \\
(\%)\end{array}$ & $\begin{array}{c}\text { Defense } \\
(\%)\end{array}$ & $\begin{array}{c}\text { Economic } \\
(\%)\end{array}$ & $\begin{array}{l}\text { Ed. } \\
(\%)\end{array}$ & $\begin{array}{c}\text { Rest of } \\
\text { social } \\
\text { Sp. }(\%)\end{array}$ \\
\hline 1900-04 & Bolivianos & $6,736,246$ & 38.88 & N.a. & 1.15 & 33.27 & 23.88 & 1.65 & 0.00 \\
\hline 1905-09 & Bolivianos & $11,437,265$ & 37.55 & N.a. & 7.70 & 22.28 & 24.82 & 7.65 & 0.00 \\
\hline 1910-14 & Bolivianos & $19,990,347$ & 47.70 & 16.74 & 11.39 & 16.90 & 13.94 & 9.00 & 0.87 \\
\hline 1915-19 & Bolivianos & $25,495,932$ & 49.75 & 31.54 & 11.29 & 17.23 & 11.92 & 8.39 & 0.93 \\
\hline $1920-24$ & Bolivianos & $37,470,691$ & 53.80 & 35.63 & 11.24 & 17.42 & 8.56 & 7.92 & 0.95 \\
\hline $1925-29$ & Bolivianos & $50,070,223$ & 50.64 & 29.95 & 11.25 & 21.05 & 7.89 & 7.96 & 1.12 \\
\hline $1930-34$ & Bolivianos & $68,954,018$ & 28.87 & 18.09 & 7.32 & 49.18 & 7.16 & 6.55 & 0.81 \\
\hline $1935-39$ & Bolivianos & $261,620,000$ & 24.09 & 9.10 & 5.81 & 44.58 & 9.66 & 6.15 & 5.33 \\
\hline $1940-44$ & Bolivianos & $1,053,020,000$ & 25.25 & 3.34 & 8.79 & 21.50 & 20.69 & 12.50 & 6.43 \\
\hline $1945-49$ & Bolivianos & $1,776,325,000$ & 20.88 & 1.91 & 11.47 & 19.82 & 8.60 & 16.77 & 6.91 \\
\hline $1950-54$ & Bolivianos & $7,554,020,000$ & 21.38 & 1.88 & 12.19 & 16.96 & 10.90 & 17.64 & 7.71 \\
\hline $1955-59$ & Bolivianos & $216,098,520,000$ & 28.22 & 2.99 & 8.09 & 9.07 & 22.80 & 14.11 & 13.85 \\
\hline $1960-64$ & Bolivianos & $474,541,520,000$ & 28.30 & 3.96 & 7.83 & 12.45 & 21.18 & 15.31 & 12.03 \\
\hline $1965-69$ & Pesos Bolivianos & $904,660,000$ & 24.43 & 4.05 & 7.80 & 16.13 & 17.18 & 28.03 & 6.42 \\
\hline $1970-74$ & Pesos Bolivianos & $2,320,800,000$ & 31.73 & D.d & D.d & 15.42 & 13.46 & 27.53 & 9.13 \\
\hline $1975-79$ & Pesos Bolivianos & $8,540,000,000$ & 19.59 & D.d & D.d & 16.19 & 20.49 & 26.54 & 14.48 \\
\hline $1980-84$ & Pesos Bolivianos & $1,435,160,000,000$ & 26.83 & D.d & D.d & 12.87 & 10.35 & 20.76 & 10.98 \\
\hline
\end{tabular}


TABLE A2 (Cont.)

\begin{tabular}{|c|c|c|c|c|c|c|c|c|c|}
\hline & Currency & $\begin{array}{c}\text { Total } \\
\text { expenditures }\end{array}$ & $\begin{array}{c}\text { General } \\
\text { public } \\
\text { services } \\
(\%)\end{array}$ & $\begin{array}{c}\text { Public debt } \\
\text { transactions } \\
(\%)\end{array}$ & $\begin{array}{c}\text { Public } \\
\text { order } \\
(\%)\end{array}$ & $\begin{array}{c}\text { Defense } \\
(\%)\end{array}$ & $\begin{array}{c}\text { Economic } \\
(\%)\end{array}$ & $\begin{array}{l}\text { Ed. } \\
(\%)\end{array}$ & $\begin{array}{l}\text { Rest of } \\
\text { social } \\
\text { Sp. }(\%)\end{array}$ \\
\hline $1985-89$ & Bolivianos & $1,390,925,000$ & 8.72 & D.d & 5.94 & 13.42 & 20.70 & 21.02 & 24.06 \\
\hline 1990-94 & Bolivianos & $4,497,760,000$ & 25.15 & D.d & 6.48 & 10.68 & 18.11 & 17.75 & 21.82 \\
\hline 1995-99 & Bolivianos & $9,225,880,000$ & 21.92 & D.d & 7.65 & 8.31 & 15.12 & 19.35 & 27.67 \\
\hline 2000-04 & Bolivianos & $16,684,828,000$ & 19.13 & D.d & 7.22 & 6.44 & 15.88 & 21.56 & 29.77 \\
\hline 2005-10 & Bolivianos & $29,591,348,333$ & 21.75 & D.d & 6.49 & 5.47 & 18.27 & 22.17 & 25.85 \\
\hline
\end{tabular}

Notes: N.a.: Not available; D.d.: Data is not disaggregated in the original source. The Bolivian currency changed from Bolivianos to Pesos Bolivianos in 1963 (1,000 Bolivianos: 1 Peso Boliviano). The Bolivian currency changed again in 1985 (1,000,000 Pesos Bolivianos: 1 Boliviano).

Sources: See the methodological appendix 


\section{BOLIVIAN PUBLIC FINANCES, 1882-2010. THE CHALLENGE TO MAKE SOCIAL SPENDING SUSTAINABLE}

\section{Methodological Appendix}

As stressed in the main text, the new dataset is based on an exhaustive archival research both in Bolivia and abroad. In Bolivia, data were gathered from the following archives and libraries: Archivo y Biblioteca del Honorable Congreso Nacional, Biblioteca del Banco Central de Bolivia, Fundación Flavio Machicado and Archivo y Biblioteca Nacional de Bolivia. Several collections have also been consulted in Spain: Fons Casa Amèrica (Universitat de Barcelona), Fons de la Cambra de Comerç (Universitat Pompeu Fabra), and Fons d'Estadística (Universitat Autónoma de Barcelona). Some data have also been collected in the United States, specifically at the Cecil Green Library (Stanford University) and the Library of Congress (Washington).

Because of data scarcity, the reconstruction of Bolivian public revenues during the last quarter of the $19^{\text {th }}$ century was made by combining different sources. Since the availability of detailed data was restricted to two single years - Memorias del Ministerio de Hacienda for 1883 and 1884 - except for external trade taxes, whose detail is available for the whole period in the 1900 National Census (Oficina Nacional de Inmigración, Estadística y Propaganda Geográfica 1904, p. XLV), it has been necessary to use Gamarra (2007, p. 142) to reconstruct aggregate revenues from 1882 to 1899. The Memorias presented an exhaustive list of all revenues collected by the Bolivian central government. The information was organised in two main groups: "Ingresos presupuestos» and "Ingresos no prespuestos». My database includes only the first group of revenues, because the second consists exclusively of financial revenues and is therefore beyond the scope of the present work. Data in the Memorias were presented in three columns: "presupuesto», "rendimiento» and "recaudado", and I have used the second one - revenue collection during the fiscal year. This information matches with the data presented in the National Census, which does not include all revenues collected, but just custom duties and export taxes.

For the first third of the $20^{\text {th }}$ century, it has been possible to find an exhaustive list of all revenues collected by the Bolivian central government in different sources: the Cuentas Generales de la República de Bolivia (1900-1918), Mc Queen (1925) (1919-1923), Memorias de la Comisión Fiscal Permanente (1924-1929) and Palenque (1933) (1930-1931) ${ }^{36}$. The linkage of these different sources did not generate any methodological problems since the figures were exactly the same in those years in which the sources coincided. For those years for which it has not been possible to find any information $(1903,1907,1916$

36 Despite its longer coverage, the estimation of Palenque (1933) has not been used for the years before 1930 because of its lower degree of detail. Palenque (1933) has only been used for 1930 and 1931 due to the inability to find other primary sources 
and 1917) the aggregate data were reconstructed using Gamarra (2007, p. 142) and Delgadillo (2001).

A priori one would expect that both the availability and quality of primary sources would increase over time. This is clearly false in the case of Bolivian public revenues, for which it has not been possible to identify a single primary source which periodically submitted detailed information on public revenues from 1932 to 1972 . Furthermore, most information is restricted to budgeted flows, which, as stated in the main text, may generate considerable biases in the analysis ${ }^{37}$. Therefore, the estimation is based on different primary sources which - albeit their lower level of disaggregation and their lack of continuity - present some data on cash flows.

In this case, however, the linkage of different sources has required a lot of caution. A previous contrast between the information presented by Delgadillo (2001), Gómez (1978) and MOxLAD pointed to considerable differences among secondary sources and to the existence of different primary sources with different information. For instance, in the case of Delgadillo's sources, the Bolivian Central Bank Yearbooks covered, among the four main official categories or public revenues, just those generated by the "Renta Aduanera» and «Impuestos Internos», ignoring therefore the «Renta de Comunicaciones» and the "Renta Consular» ${ }^{38}$. Similarly, in the case of Mitchell's data - which is the main source of the MOxLAD database - revenues generated by foreign exchange controls are ignored from 1936 to 1939 and from 1952 to 1956. In the following paragraphs I specify the sources that I finally used in my estimation and all the corrections made on the original figures.

Figures for the period 1932-1935 are based on the Memoria del Banco Central de 1936, which was the only source that presented disaggregated data for those years ${ }^{39}$. Two sporadic publications which displayed detailed information on Bolivian public revenues were used for the estimation of disaggregated revenues from 1942 to 1944: Finanzas 1942-1943 and Anexo No. 1 of the Memoria del Ministerio de Hacienda ${ }^{40}$. Estimates for the period 1947-1951 are based on the Memoria del Banco Central de 1951. However, in order to consider all the revenues collected by the central government, those

37 Wilkie (1969, p. 53) indicates that the Bolivian government stopped publishing cash-revenues from 1934, and that his estimation of Bolivian public expenditures is based on several accounting books located at the warehouse of the Ministry of Finance. Despite the visit to several archives, it has not been possible to find these books to use them in the present research.

38 Those four categories were used in the Bolivian public finance accounts from the late 1930s to the early 1980s: see Finanzas (1942), Estadística Financiera (1959), Estadística Financiera (1963), Informe de Labores (1966-1967) and Otálora (1995).

39 The sum of all revenue categories did not match the aggregate figure presented in this source for 1934. Therefore, I increased the amount of «Gravámenes a la Industria Nacional», which was a clear outlier during that year.

${ }^{40}$ Again, the sum of all revenue categories did not match the aggregate figure presented in this source for 1942, and I therefore assumed the difference to correspond to the "Derechos arancelarios", whose amount was not reported in the source. 
coming from the «Renta Consular» and «Renta de Comunicaciones» available in Boletín Estadístico No. 83 del Ministerio de Hacienda (1959) were added to the original source. Finally, aggregate data for other years are based on Delgadillo (2001)for 1936 and 1937 and the Boletín Estadístico No. 83 del Ministerio de Hacienda (1959) for the remaining years.

Two different types of sources were available for the period 1952-1963: the UN Statistical Yearbooks and some scattered publications of the Ministry of Finance. Whereas both groups of documents may be useful for reconstructing the structure of public revenues, my database is mainly based on the former, since the information is organised there according to the international standards that have been adopted in this research. For those years for which disaggregated data were not available (1952, 1954 and 1960), aggregate figures were taken from the Boletín Estadístico No. 83 del Ministerio de Hacienda (1959). There are some years of this period for which the information available is very different in the different sources. In those cases I have given preference to UN data.

The UN yearbooks no longer present detailed Bolivian public finance data after 1963. Therefore, aggregate revenues for the period 1964-1969 were reconstructed on the basis of the International Financial Statistics published by the IMF. The UDAPE's (1986) survey allowed a disaggregated reconstruction of public revenues for 1970-1972. The linkage between these two sources was not problematic since they presented more or less the same aggregate figures.

From the 1970s onwards, two long series are available which display disaggregated data of central government's revenues. The first is the aforementioned survey made by UDAPE (1986), which covers the period 19701985. The second is the IMF Government Finance Statistics, which presents disaggregated data from 1973 onwards. My database is based on the latter for two reasons: (a) the greater length of the series, (b) its higher adaptation to international standards. However, there is no significant difference between these two sources.

The reconstruction of the revenue structure for both central and general government from 1990 to 2010 benefits from the availability of on-line information Moreover, this information is provided by three different institutions: UDAPE, the Economic Commission for Latin America (ECLAC) and the IMF (although the IMF general government data only starts in 2002). Despite this data abundance, it is still necessary to make a careful analysis of the different sources, because not all of them display the information in the same way. For instance, the structure of revenues in the UDAPE website is based on an idiosyncratic Bolivian classification and, therefore, requires a complete reallocation of the different revenues to adapt them to international criteria. In addition, the statistical information provided by the three sources does not match perfectly. A comparison between the three sources indicates that UDAPE tends to overestimate tax revenues by classifying as taxes some revenues that can hardly be 
considered as such by international standards. I have finally relied on the ECLAC series, because they organise the information according to international classifications, and have a greater time span in the case of the general government statistics than the IMF. Moreover, since the aggregate figures of both ECLAC and IMF are very similar, the link of the ECLAC data with the estimates for the previous period does not involve any difficulty.

As for public spending, I have used the Cuentas Generales de la República de Bolivia for the reconstruction of each ministerial expenditure from 1900 to 1909. This information has been linked with Palenque (1933), which is also based on the Cuentas Generales for 1911-1931. For the period 1932-1966 I have used the disaggregated data provided by Wilkie (1969). The linkage between Palenque's and Willkie's series is not problematic since differences between both series are always lower than 1 per cent in those years in which both series coincided (1930 and 1931). On the other hand, my series is ca. 2 per cent higher than Wilkie's because I included earmarked expenditures («Gastos destinados»; those expenditures that were directed to very specific destinations and were financed through very specific taxes) among «Other expenditures». For 1967-1972, I used the information available in Estadísticas Económicas de USAID, which presents the same data as Wilkie, but with a higher degree of aggregation. Finally, the 1973-2010 period has been reconstructed by using the IMF Government Financial Statistics CD-database.

The distribution of revenue and expenditure among different categories has followed the most widely accepted international definitions (IMF 2001). The database is organised according to an adapted version of the IMF functional classification (IMF 2001) which considers three general categories with several sub-categories in the case of revenues and six categories and three sub-categories in the case of expenditures (Table A3).

The new database represents substantial progress in comparison with the previously available evidence in the Bolivian historiography. In the case of revenues, for instance, whereas Delgadillo (2001) offers aggregate data for 1900-1960 and Gómez (1978)for 1900-1970, my revenue estimation provides detailed data from 1882 to $2010^{41}$. As shown in Figure A1, my figures are identical to those previous estimations from 1900 to 1937. After this year some differences emerge between the series, which are not surprising given the higher uncertainty of the public finance statistics available for that period. The highest differences are found between 1957 and 1963, and can be explained by the fact that Gómez's data include donations, a category which was particularly important during those years but has been deliberately removed from my estimation which focuses on current revenues. In fact, after 1964, once the relative importance of donations started to decrease, both estimations tend to converge again.

41 Likewise, the IMF International Statistics or the United Nations yearbooks only provide information since 1950 . 
TABLE A3

CURRENT REVENUE AND TOTAL EXPENDITURE CLASSIFICATION

\begin{tabular}{|c|c|c|c|}
\hline \multirow[t]{13}{*}{ Current revenue } & \multirow[t]{10}{*}{ Taxes } & \multirow[t]{3}{*}{ Direct } & $\begin{array}{l}\text { Income, profits and } \\
\text { capital gains }\end{array}$ \\
\hline & & & Payroll and workforce \\
\hline & & & Property \\
\hline & & \multirow[t]{3}{*}{ Indirect internal } & general taxes \\
\hline & & & Excises \\
\hline & & & On the use of goods \\
\hline & & \multirow[t]{3}{*}{ On international trade } & $\begin{array}{l}\text { Custom and other } \\
\text { import duties }\end{array}$ \\
\hline & & & Taxes on exports \\
\hline & & & $\begin{array}{l}\text { Exchange profits and } \\
\text { exchange taxes }\end{array}$ \\
\hline & & Other taxes & \\
\hline & \multirow[t]{2}{*}{ Non-tax revenues } & Property income & \\
\hline & & $\begin{array}{l}\text { Sales of goods and services } \\
\text { Other non-tax revenues }\end{array}$ & \\
\hline & Social Contributions & & \\
\hline \multirow[t]{9}{*}{ Total expenditure } & General Public Services & & \\
\hline & Public order and safety & & \\
\hline & Defense & & \\
\hline & Economic Affairs & & \\
\hline & \multirow[t]{4}{*}{ Social Public Expenditure } & Education & \\
\hline & & Health & \\
\hline & & Welfare & \\
\hline & & Others & \\
\hline & Others & & \\
\hline
\end{tabular}

Sources: IMF (2001: 49, 76).

Figures A2 and A3 compare my estimation with the equivalent figures reported by the widely utilised MOxLAD database. The similarity between both revenue series (Figure A2) is only broken during the late 1970s because of a 
FIGURE A1

ALTERNATIVE ESTIMATES OF BOLIVIAN CENTRAL GOVERNMENT'S REVENUES, 1900-1970 (MILLIONS BS. 2000)

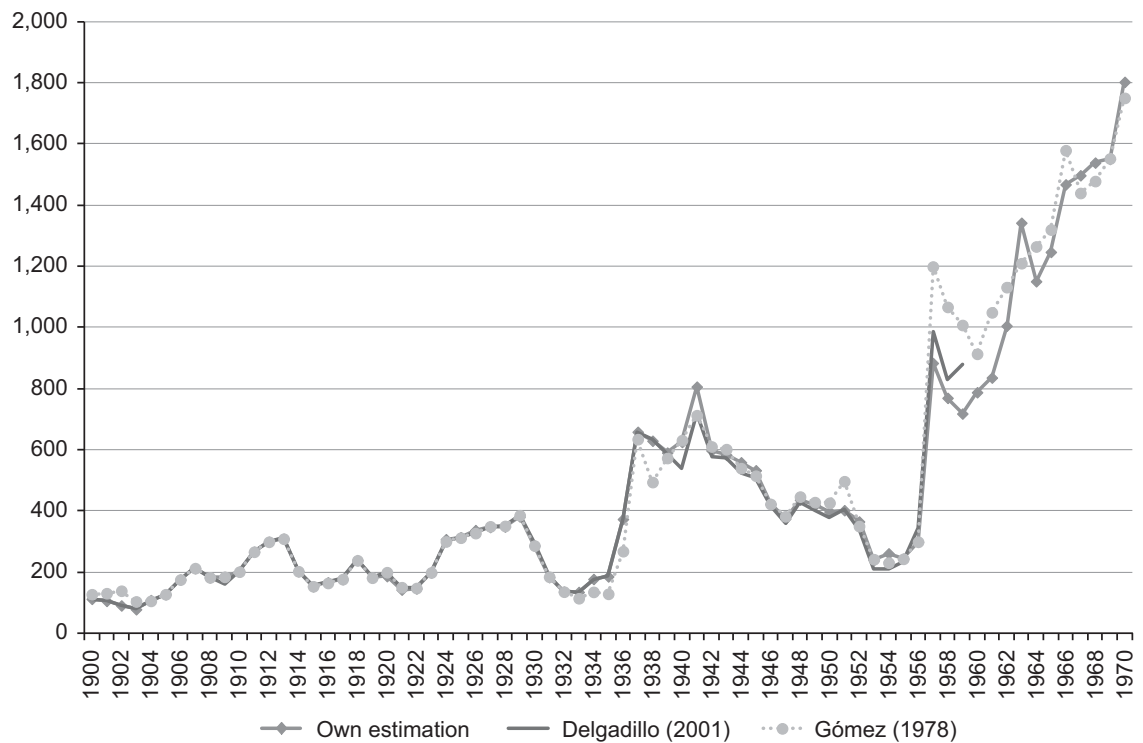

Sources: Delgadillo (2001), Gómez (1978) and my own figures.

Notes: The three series have been deflated using the price index presented in the main text.

decrease in MOxLAD series that is difficult to explain ${ }^{42}$. In the case of expenditures (Figure A3), some level differences are occasionally identifiable from 1900 to 1985 which are also difficult to explain, but might be the result of differences in either the unit of observation or the primary sources used in the estimation ${ }^{43}$.

42 According to the MOxLAD series, Bolivian public revenues started to decrease in 1976, but this is difficult to believe, given the economic dynamism of that year - with a GDP growth rate of 6.1 per cent. In contrast, my series suggest that Bolivian public revenues started to decrease in 1979, which is consistent with the simultaneous crisis of the economy - the growth rates of GDP and GDP per capita being -0.02 per cent and $-2.33 \%$, respectively. The information provided by local sources (UDAPE 1986) is in line with my estimation.

43 From 1900 to 1985 the MOxLAD revenue and expenditure series are based on Mitchell (2003). The origin of the series offered by this author is not clear. For instance, he offers data on Bolivian public expenditure from 1888 to 1895 based on an estimation whose source is not clarified. In relation to this, despite I have consulted several primary sources. I was not able to find any series of Bolivian public expenditure during this period of time. Likewise, Mitchell's data from 1896 to 1970 refer to Federal [sic] Government. Since the Bolivian state has never had a federal organisation, it is difficult to know what exactly is measured by the author. In any case, if Mitchell wants to refer to the Bolivian central government, the level differences between his estimates and my series may be reflecting differences in primary sources. From 1900 to 1972, Mitchell obtained the information from the so-called "Boletín Estadístico», whereas my estimates are based on the sources 
FIGURE A2

MOXLAD AND MY ESTIMATES OF BOLIVIAN CENTRAL GOVERNMENT'S

REVENUES, 1882-2010 (TEN MILLIONS BS. 2000)

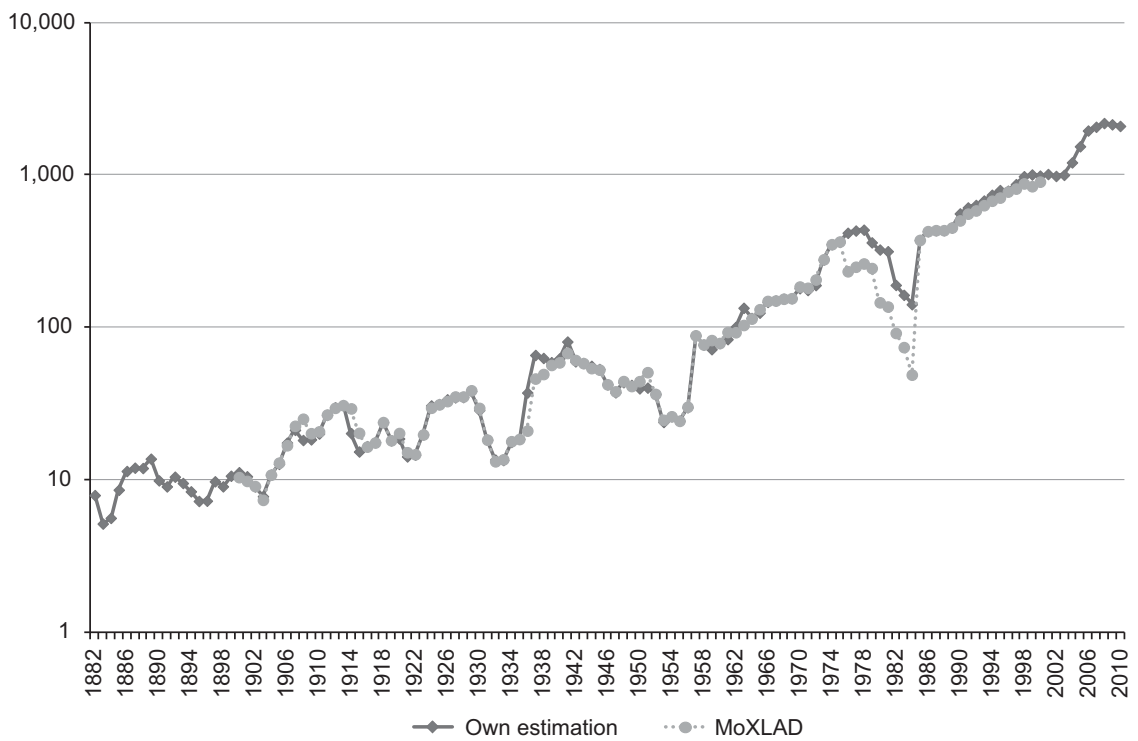

Sources: MOxLAD database: http://moxlad.fcs.edu.uy/, and my own figures.

Notes: Both series have been deflated using the price index presented in the main text.

These differences disappear from 1985 onwards, when both series are based on the IMF statistics.

In addition, my database provides disaggregated figures for different categories of both public revenues and expenditures. To date and to my knowledge, this is the first disaggregated estimation with such a long time span and, as discussed in the main text, it constitutes an essential instrument to obtain an adequate understanding of the role of the state in the Bolivian economy since the late $19^{\text {th }}$ century.

\section{References}

\section{Statistical Sources}

IMF

Finanzas del Ministerio de Hacienda (1942)

(F'note continued)

presented above. From 1973 to 1984, he obtained the information from the so-called «Bolivian en cifras», whereas my estimation comes from the original data published and revised by the IMF. 
FIGURE A3

MOXLAD AND MY ESTIMATES OF BOLIVIAN CENTRAL GOVERNMENT'S EXPENDITURES, 1900-2010 (TEN MILLIONS BS. 2000)

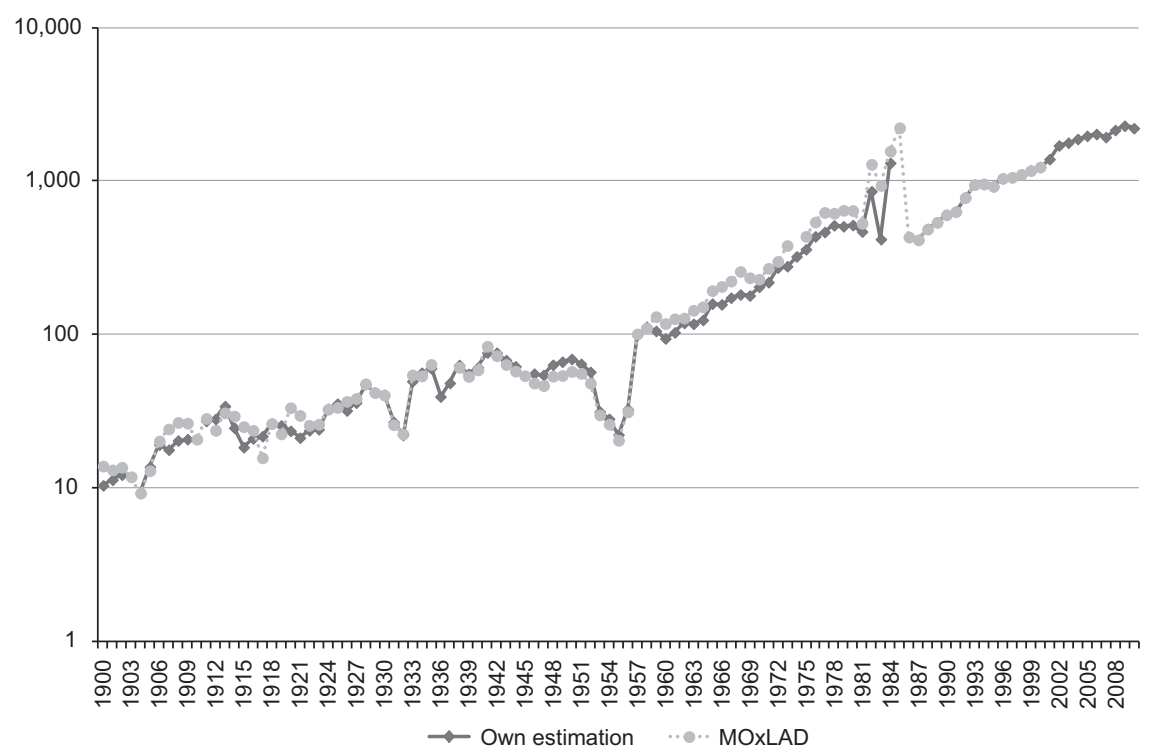

Source and note: See Figure 2.

Estadística Financiera (1959-1963)

Informe de Labores del Ministerio de Hacienda (1966-1967)

International Financial Statistics (1960-1972)

Government Finance Statistics (1973-2007)

REPÚBLICA DE BOLIVIA

Finanzas del Ministerio de Hacienda (1942)

Estadística Financiera (1959-1963)

Informe de Labores del Ministerio de Hacienda (1966-1967)

Boletín Estadístico No. 83 del Ministerio de Hacienda (1959)

Cuentas Generales de la República de Bolivia (1900-1918)

Memorias del Ministerio de Hacienda (1872-1917)

Memorias de la Comisión Fiscal Permanente (1924-1929)

Memorias del Banco Central de Bolivia (1929-2007)

REPÚBLICA DE BOLIVIA. OFICINA NACIONAL DE INMIGRACIÓN, ESTADÍSTICA Y PROPAGANDA GEOGRÁFICA (1904) Censo General de la Población de la República de Bolivia de 1900. Taller Tipo-Litográfico José M. Gamarra: La Paz. 
UN

Statistical yearbooks (1948-1970)

USAID

Estadísticas Económicas de Bolivia (1967-1972).

\section{Websites}

Economic Commission for Latin America and the Caribbean: http:// www.eclac.cl/

Montevideo and Oxford Latin America Database: http://moxlad.fcs.edu.uy/ Unidad de Análisis de Políticas Ecómicas: http://www.udape.gob.bo

\section{Publications}

Delgadillo, H. (2001): "Apéndice Estadístico», in H. Huber Abendroth; N. Pacheco; C. Villegas; Á. Aguirre, and H. Delgadillo, La deuda externa de Bolivia-125 años de renegociaciones y cuantos más? : desde la operación secreta del gobierno y los Meiggs hasta la iniciativa HIPC. La Paz: CEDLA/ OXFAM, pp. 401-539.

Gamarra, M. P. (2007): Amazonía Norte de Bolivia, economía gomera (1870-1940). Bases económicas de un poder regional. La casa Suárez. La Paz: CIMA.

Gómez, W. (1978): La minería en el desarrollo económico de Bolivia, 1900-1970. La Paz: Editorial Los Amigos del Libro.

Mitchell, B.R. (2003). International historical statistics: the Americas, 1750-2000. Palgrave Macmillan: Houndmills.

MC QueEn, C. (1925): Bolivian public finance. Washington: Department of State.

Otálora, C. R. (1995): «La Política Fiscal Boliviana entre 1975 y 1989», in J. A. Morales and G. La Torre (eds), Inflación, estabilización y crecimiento. La experiencia boliviana de 1982 a 1993. La Paz: IISEC/UCB, pp. 83-141.

Palenoue, J. (1933): «Análisis numérico del presupuesto nacional», in Estadística Boliviana. Primera Parte. Años 1911-1931. La Paz.

Udape (1985): Diagnoestico de Situacioen del Sistema Tributario en Bolivia. UDAPE: La Paz

UdAPE (1986): Las estadísticas fiscales de Bolivia, período 1970-1985. La Paz: UDAPE.

WILKIE, J. W. (1969): The Bolivian revolution and U.S. aid since 1952; financial background and context of political decisions. Los Angeles: Latin American Center, University of California. 